\title{
Microbial responses to selected pharmaceuticals in agricultural soils: Microcosm study on the roles of soil, treatment and time
}

\author{
Z. Frková ${ }^{\mathrm{a}, \mathrm{b}}$, Y. Vystavna ${ }^{\mathrm{a}, \mathrm{c}}$, A. Koubováa ${ }^{\mathrm{a}, \mathrm{d}}$, P. Kotas ${ }^{\mathrm{e}}$, K. Grabicová ${ }^{\mathrm{d}}$, R. Grabic ${ }^{\mathrm{d}}$, R. Kodešová ${ }^{\mathrm{f}}$, \\ A. Chroňáková ${ }^{\text {a, }}$ \\ ${ }^{a}$ Institute of Soil Biology, Biology Centre CAS, Na Sádkách 7, 37005, České Budějovice, Czech Republic \\ ${ }^{\mathrm{b}}$ Faculty of Science, Technology and Communication, University of Luxembourg, 6, Rue Richard Coudenhove-Kalergi, L-1359, Luxembourg \\ ${ }^{\mathrm{c}}$ Institute of Hydrobiology, Biology Centre CAS, Na Sádkách 7, 37005, České Budẽjovice, Czech Republic \\ ${ }^{\mathrm{d}}$ Faculty of Fisheries and Protection of Waters, South Bohemian Research Center of Aquaculture and Biodiversity of Hydrocenoses, University of South Bohemia in České \\ Budějovice, Zátiší 728/II, 38925, Vodñany, Czech Republic \\ ${ }^{\mathrm{e}}$ Faculty of Science, University of South Bohemia in České Budějovice, Branišovská 31, 37005, České Budějovice, Czech Republic \\ ${ }^{\mathrm{f}}$ Faculty of Agrobiology, Food and Natural Resources, Czech University of Life Sciences, Kamýcká 129, 16521, Praha 6, Suchdol, Czech Republic
}

\section{A R T I C L E I N F O}

\section{Keywords:}

Emerging compounds

Micropollutants

Basal respiration

PLFA

Microbial biomass

\begin{abstract}
A B S T R A C T
Evaluating microbial responses to pharmaceuticals in agricultural soils is essential to improve our fundamental understanding of the fate of micropollutants and their potential implications for the environment and human health. In this study, we focused on the immediate $(1 \mathrm{~d})$, short- $(13 \mathrm{~d})$ and long-term effects (61 d) of pharmaceutical amendment on microbial communities in seven soils differing in physical chemical properties. Basal respiration was used to indicate microbial activity, while phospholipid fatty acids were used to determine microbial biomass and community structure. We identified four microbial responses to pharmaceutical amendment: stimulation, inhibition, stress and dormancy, which were highly significant in the short-term. The largest stimulatory effect accompanied by shifts in the microbial community structure towards fungi and G- bacteria was detected for sulfamethoxazole. The inhibitory effect was mainly observed for citalopram, irbesartan and pharmaceutical mixture in Cambisol Dystric with minor alterations in microbial community structure compare to a non-amended control. The stress effect was detected for all pharmaceuticals in Arenosol and Cambisol Haplic. While the dormancy effect was mainly observed in Chernozem Siltic for most of the pharmaceuticals. Microbial responses were highly dependent on the soil type, pharmaceutical compound and time, highlighting the importance to consider these parameters including a resilience of soil microbial communities to micropollutants within a long-term agricultural soil management.
\end{abstract}

\section{Introduction}

Pharmaceuticals and their transformation products enter the soil with manure, biosolids and/or the reuse of treated wastewater (Gottschall et al., 2012; Ivanová et al., 2018; Kinney et al., 2006; Klement et al., 2020; Kümmerer, 2009; Kyselková et al., 2013; Monteiro and Boxall, 2009). After being introduced into the environment, these emerging contaminants affect soil microorganisms, invertebrates, plants and even reach groundwater, which enters the food chain, posing an environmental and health risk (Carter et al., 2014; Gielen et al., 2011; Jurado et al., 2019; Kodešová et al., 2019a, 2019b; Vystavna et al., 2017). It should be considered that pharmaceuticals are designed to have a biological effect at low doses, acting on physiological systems that can be evolutionarily conserved across taxa (Elizalde-Velázquez et al., 2019).

After being introduced into soil, pharmaceuticals were found to be adsorbed on organic matter and clay minerals but were also found processed via chemical and microbial degradation (Grossberger et al., 2014; Fer et al., 2018; Klement et al., 2018; Biel-Maeso et al., 2019; Schmidtová et al., 2020). Multiple factors control the fate of pharmaceuticals, including the physical and chemical characteristics of soil and the introduced pharmaceuticals, as well as the ability of microbes to degrade these emerging compounds (Topp et al., 2008; Lin and Gan, 2011; Li et al., 2013; Srinivasan and Sarmah, 2014). The sorption

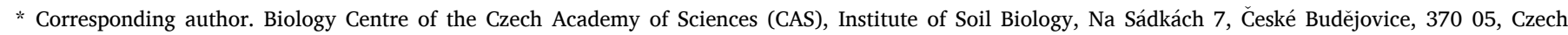
Republic.

E-mail address: alica.chronakova@upb.cas.cz (A. Chroňáková).
} 
affinity of soil, which is a principle factor controlling the bioavailability of chemicals, is determined by soil moisture, organic carbon and clay contents, $\mathrm{pH}$, bioactivity and initial climate conditions (temperature, relative humidity, precipitation) (Grossberger et al., 2014; Kodešová et al., 2016, 2015; Fer et al., 2018). The sorption capacity of pharmaceuticals is mainly related to their polarity and degree of dissociation (Kodešová et al., 2015). The sorption of non-ionic (neutral) molecules is driven by hydrophobic partitioning to soil organic matter and its content and by hydrogen bonding with hydroxyl groups on solid surfaces. The sorption of cationic molecules is mainly governed by the attraction of the solid surface (e.g., a clay mineral surface or organic matter) to negative charges and thus is controlled by the cation exchange capacity or by the basic cation saturation (Kodešová et al., 2015; Fer et al., 2018; Klement et al., 2018; Schmidtová et al., 2020).

Chemical and photochemical degradation of pharmaceuticals is determined by various reactions, including oxidation, hydroxylation, decarboxylation and demethylation (Rubasinghege et al., 2018). However, studies confirm that among these processes, microbial degradation (biodegradation) is a key mechanism of pharmaceuticals transformation in soil (De Groot et al., 2002; Xu et al., 2009; Rodarte-Morales et al., 2011; Topp et al., 2013; Biel-Maeso et al., 2019). Biodegradation, which is understood as the transformation of organic compounds into metabolites, microbial biomass, extractable and non-extractable residues, is highly related to microbial activity (Gielen et al., 2011; Cycoń et al., 2019). Previous studies (Kodešová et al., 2016; Koba et al., 2016, 2017) have found that the degradation of pharmaceuticals in soils (taken from surface horizons), but also the formation, and follow-up degradation of their metabolites are strongly soil type-dependent and are associated with differences in overall soil quality (i.e., texture, water and nutrient content, etc.). Microbial degradation in laboratory experiments has shown the dependence on the nutrient supply (Vasiliadou et al., 2013; Popa Ungureanu et al., 2014), on the existence of positive synergetic effects of different microorganisms (Larcher and Yargeau, 2011) or on the co-metabolic potential of different chemical compounds (Gauthier et al., 2010). Most recent studies have highlighted that pharmaceuticals affect the soil microbial community by both stimulating and inhibiting microbial respiration and biomass, indicating diverse microbial responses to exposure to pharmaceuticals in soil (Gielen et al., 2011; Cycoń et al., 2019).

Studies on microbial response to pharmaceuticals in soil have mainly focused on the impact of antibiotics on microbial activity and communities (Liu et al., 2012; Ding et al., 2014; Jechalke et al., 2014), exposure to a single pharmaceutical compound (Srinivasan and Sarmah, 2014), exposure to high concentrations (Cycoń et al., 2016; Pino-Otín et al., 2017), exposure during a short-term incubation period (up to 21 days) (Pino-Otín et al., 2017), and/or a single soil type (Liu et al., 2009; Gutiérrez et al., 2010; Cycoń et al., 2016). To the best of our knowledge, no comprehensive study has been reported on microbial responses in terms of microbial respiration, biomass and community shifts to understand the time-varying effect of environmentally relevant concentrations of pharmaceuticals and their mixture applied to various agricultural soils differing in physical chemical properties. This knowledge gap became the overall goal of our study, which had the following objectives: i) to explore the trends in residual concentrations of amended pharmaceuticals in a wide range of soil types; ii) to assess the effects of pharmaceutical amendment to soils on basal respiration, microbial biomass and community structure; and iii) to determine and describe microbial responses to pharmaceuticals in soil in immediate (1 day), short-term (13 days) and to evaluate the resilience of the community after additional 48 days (long-term, $61 \mathrm{~d}$ ). To address these tasks, we measured concentrations of pharmaceuticals, basal respiration and PLFA community profiles in soils amended with selected pharmaceuticals and their mixture and non-amended (controls) in respective exposure times. Using both basal respiration and PLFA analysis we could follow the responses of whole soil microbial communities, and not only their particular populations. In addition, PLFA enables quantitative calculations of microbial biomass of active taxa, thus indicating their relative contributions to ecosystem functioning (e. g. Frostegård et al., 2011; Kotas et al., 2018).

The novelty of this multidisciplinary research lies in the application of a complex approach to determine microbial responses to environmental concentrations of pharmaceuticals in a wide range of agricultural soils, in which different degradation and transformation patterns were observed for selected pharmaceuticals (Kodešová et al., 2016;Kodešová et al., 2020; Koba et al., 2016, 2017). The proposed multi-parameter approach allowed us to find a link between biotic (basal respiration, microbial biomass and community structure) and abiotic parameters (pharmaceuticals concentration and soil physical chemical properties) that was summarized in a conceptual scheme.

\section{Material and methods}

\subsection{Chemicals and soil properties}

Six pharmaceuticals with different properties from diverse therapeutic classes (two antibiotics, clindamycin and sulfamethoxazole, anticonvulsant carbamazepine, antidepressant citalopram, antihistaminic fexofenadine and angiotensin receptor blocker irbesartan) were selected for our study (SI-1). The selection was based on the widespread occurrence of these pharmaceuticals in wastewater, surface water and groundwater as well as their possible veterinary applications (i.e., clindamycin, fexofenadine and sulfamethoxazole) and detection in manure (Fedorova et al., 2014; Golovko et al., 2014a, 2014b; Gottschall et al., 2012; Vystavna et al., 2017, 2019). All chemicals were of analytical purity ( $\geq 98 \%$ ). Stock solutions of the pharmaceuticals were prepared in ethanol (96\%, Penta, Prague, Czech Republic) at a concentration of $1 \mathrm{mg} \mathrm{mL}^{-1}$, and subsequent dilutions were performed in a tap water.

A mixture of native standards and their metabolites (trans-10,11dihydro-10,11-dihydroxy carbamazepine, 10,11-dihydro carbamazepine, carbamazepine 10,11-epoxide, N-desmethylcitalopram, clindamycin sulfoxide, N1- and N4-acetyl sulfamethoxazole; suppliers are given in SI-1) was used to generate the calibration curve and matrixmatching standard. Isotopically labelled standards (carbamazepineD8, citalopram-D6, clindamycin-D3, fexofenadine-D6, irbesartan-D4 and sulfamethoxazole-D4; all from Toronto Research Chemicals, North York, ON, Canada) were used as internal standards for the quantification of pharmaceuticals in soil. Acetonitrile and isopropanol (both LC/MS grade, Merck, Darmstadt, Germany) were used as extraction solvents. Acidified (formic acid, $>98 \%$, Sigma Aldrich, Darmstadt, Germany) acetonitrile and ultra-pure water (AquaMax Basic 360 Series and Ultra 370 Series, Young Lin Instruments, Anyang, Korea) were used as mobile phases for liquid chromatography.

Seven of eleven arable soils, which were previously tested by (Koba et al., 2017, 2016; Kodešová et al., 2016), were evaluated in this study: Stagnic Chernozem Siltic (Chernozem S), Haplic Chernozem (Chernozem H), Greyic Phaeozem (Phaeozem), Haplic Luvisol (Luvisol), Dystric Cambisol (Cambisol D), Haplic Cambisol (Cambisol H), and Arenosol Epieutric (Arenosol), ordered according to the progressive deterioration of soil quality (following parent material and oxidizable carbon values, $\mathrm{C}_{\mathrm{ox}}$ ). The selected soils cover the majority of soil types that occur in Central Europe (European Soil Bureau Network European Commission, 2005), differ in physical chemical properties (SI-2), and have diverse degradation and transformation patterns for the tested pharmaceuticals (i.e., carbamazepine, clindamycin, sulfamethoxazole, trimethoprim, clarithromycin, atenolol and metoprolol (Kodešová et al., 2016)).

\subsection{Experimental set-up}

A degradation experiment was developed according to OECD (2002). Soils were collected from the surface layer (at the depth of $0-25 \mathrm{~cm}$ ); air- 
dried; and homogenized ( $2 \mathrm{~mm}$ sieve). The time needed for sample preparation did not exceed 5 days. Fifty grams of air-dried soil was transferred to $100-\mathrm{mL}$ polyethylene bottles, irrigated with $6 \mathrm{~mL}(3 \mathrm{~mL}$ in the case of Arenosol) of tap water and pre-incubated in the dark at $20^{\circ} \mathrm{C}$ for 6 days. Next, each soil was amended with $6 \mathrm{~mL}$ ( $4 \mathrm{~mL}$ in the case of Arenosol) of a solution containing different pharmaceuticals (concentrations of 8.3 and $12.5 \mu \mathrm{g} \mathrm{mL}^{-1}$, respectively) and was mixed thoroughly by shaking for $30 \mathrm{~s}$. The amounts of added tap water and solution approximately corresponded the half and full field water holding capacity, respectively, according to (Kodešová et al., 2016). The final concentration was approximately $1 \mu \mathrm{g} \mathrm{g}^{-1}$ per compound of dry soil weight (dw) as previously used in other environmental studies (Grossberger et al., 2014; Monteiro and Boxall, 2009; Srinivasan and Sarmah, 2014). All the treatments, including the six individual pharmaceuticals, their mixture (at a concentration ratio $1: 1: 1: 1: 1: 1$ ) and the non-amended control (with no pharmaceutical addition), were carried out in triplicate for each soil type. Soils were incubated at $20^{\circ} \mathrm{C}$ in the dark and were destructively sampled at predefined times (after $0,1,13$ and 61 days) to represent non-amended control $(0 \mathrm{~d})$, immediate $(1 \mathrm{~d})$, short- $(13 \mathrm{~d})$ and long-term (61 d) effects.

Here is important to highlight that all tests have been carried out with a single amendment of the pharmaceuticals. A repetitive amendment of the compounds to soils should be the objective of a future study. Additionally, it should be considered that not all processes of the given soils under the real conditions may be included in a single microcosm study. Microcosms are simplified, physical models of an ecosystem that enable controlled experiments to be conducted in the laboratory or in situ and serve as a proxy to study the specific environmental processes that cannot be easily controlled at the larger scale (Matheson, 2008).

\subsection{Soil extraction and pharmaceutical analysis}

The method used for extraction was identical to that published by (Kodešová et al., 2016). The extracts were analysed by liquid chromatography with a high-resolution mass spectrometry (LC-HRMS) method according to (Koba et al., 2017, 2016).

Briefly, the whole contents of the bottle were extracted with mixtures A (acetonitrile/water mixture $-1: 1 \mathrm{v} / \mathrm{v}$, with $0.1 \%$ of formic acid) and $\mathrm{B}$ (acetonitrile/2-propanol/water mixture - 3:3:4 v/v/v, with $0.1 \%$ formic acid) in three consequent steps (A:B:B, 60:35:20 mL) using an ultrasonic bath. All subsequent supernatants were combined, and $10-\mathrm{mL}$ aliquots were filtered through a syringe filters (regenerated cellulose, $0.45 \mu \mathrm{m}$ ) and stored for LC-HRMS analysis. Aliquots of $100 \mu \mathrm{L}$ were collected and placed in autosampler vials, and internal standards were added and analysed by LC-HRMS. The analytical system consisted of an analytical LC pump Accela 1250 (Thermo Fisher Scientific, San Jose, USA), HTS XT-CTC autosampler (CTC Analytics AG) and a Q-Exactive plus mass spectrometer (Thermo Fisher Scientific). A Hypersil Gold aQ column ( $50 \mathrm{~mm} \times 2.1 \mathrm{~mm}$ i.d., $5 \mu \mathrm{m}$ particle size, Thermo Fisher Scientific) was used for chromatographic separation of the target compounds according to (Koba et al., 2016). The analytes were ionized by a heated electrospray and were analysed in the positive full scan mode at a resolution of $70000 \mathrm{FWHM}$. The spray voltage was set to $2.8 \mathrm{kV}$, capillary temperature to $325^{\circ} \mathrm{C}$ and auxiliary gas heater temperature to $250{ }^{\circ} \mathrm{C}$. Nitrogen was used as the sheath gas (40 arbitrary units) and auxiliary gas (10 arbitrary units). Detailed information regarding the analytical conditions are described in SI-3. The matrix effects were corrected using a matrix matching standard if the deviation from calibration curve response factor was greater than $30 \%$ according to (Golovko et al., 2016; Koba et al., 2017). The obtained data were processed with TraceFinder 3.3 software (Thermo Fisher Scientific). The limits of quantification for the individual compounds in soil did not exceed $3.7 \mathrm{ng} \mathrm{g}^{-1}$ (SI-3).

The determined concentration of each target analyte was recalculated to a molar concentration ( $\mathrm{pmol} \mathrm{g}^{-1} \mathrm{dw}$ soil) by dividing the weight concentration by the corresponding molecular mass of the studied compound, which was not dependent on the molecular mass of each analyte. To assess pharmaceutical degradation over time and facilitate comparisons among soils and individual treatments, the data are described as relative residual concentrations corresponding to the difference between $c_{0}$ and $c_{t}$ (concentration in time).

\subsection{Microbial analyses}

Basal respiration was estimated from the headspace $\mathrm{CO}_{2}$ accumulation rates (Anderson and Domsch, 1985). In brief, $5 \mathrm{~g}$ of soil in 100-mL Duran bottles was sealed with a butyl rubber stopper and tightly closed with a bottle cap. After $1 \mathrm{~h}$ of incubation at $22^{\circ} \mathrm{C}$, the $\mathrm{CO}_{2}$ in the head space was determined on an Agilent HP 5890 series II gas chromatograph (GC) equipped with a thermal conductivity detector (TCD) and a capillary column Agilent HP-Plot Q operated at $60^{\circ} \mathrm{C}$. Additionally, at each time point, subsamples for phospholipid fatty acid (PLFA) extraction and dry matter measurements were obtained. The PLFA method served as a rapid assessment of the microbial biomass and composition of microbial communities in soil since many PLFAs are indicative of microbial groups in soil. In addition, the ratios of the biomasses of bacteria/fungi (B/F) and Gram-positive/Gram-negative (G+/G-) bacteria were used to evaluate the response of microorganisms to organic pollutants (Frostegård et al., 1993, 2011; Liu et al., 2016). The extraction of PLFA was performed according to (Bligh and Dyer, 1959) with modifications by (Frostegård et al., 1993). In total, 1-2.5 g of the lyophilized soil sample (according to the soil $\mathrm{C}_{\mathrm{ox}}$ ) was placed in a baked test tube and extracted with 4.75-9.5 mL (according to the sample weight) of chloroform/methanol/phosphate buffer (1:2:0.8 v/v/v) for 2 $\mathrm{h}$ at room temperature in the dark. After centrifugation (3500 RPM, 5 $\min , 20^{\circ} \mathrm{C}$ ), the supernatants from the two subsequent extractions were pooled and separated into two phases by the addition of $2-4 \mathrm{~mL}$ (according to the sample weight) chloroform/buffer $(1: 1 \mathrm{v} / \mathrm{v})$. The lipids from the lower phase were fractioned through silicic acid-columns, LiChrolut Si 60 (Merck, Germany). Phospholipids were eluted with 2 $\mathrm{mL}$ methanol and subjected to mild alkaline metanolysis according to (Dowling et al., 1986). Samples were analysed on an Agilent Trace 1310 GC (Agilent, Wilmington, Delaware, USA) equipped with a flame ionization detector and a $60 \mathrm{~m} \times 0.32 \mathrm{~mm}$ BPX70 $\times 0.25 \mu \mathrm{m}$ column (SGE Analytical Science), with $\mathrm{H}_{2}$ and air flow of 35 and $400 \mathrm{~mL} \mathrm{~min}^{-1}$, respectively, and $\mathrm{N}_{2}$ at $28 \mathrm{~mL} \mathrm{~min}^{-1}$. The initial oven temperature was $110{ }^{\circ} \mathrm{C}$ following the temperature gradient: $5.5 \mathrm{~min}$ : increase $12{ }^{\circ} \mathrm{C}$ $\min ^{-1}$ to $140{ }^{\circ} \mathrm{C}$; $13.5 \mathrm{~min}$ : increase $5^{\circ} \mathrm{C} \mathrm{min}^{-1}$ to $180^{\circ} \mathrm{C}$; $40.167 \mathrm{~min}$ : increase $1.5^{\circ} \mathrm{C} \mathrm{min}-1$ to $220^{\circ} \mathrm{C} ; 45.917 \mathrm{~min}$ : increase $8^{\circ} \mathrm{C} \mathrm{min}{ }^{-1}$ to 250 ${ }^{\circ} \mathrm{C}$; and $50.317 \mathrm{~min}$ : decrease $250{ }^{\circ} \mathrm{C}-140{ }^{\circ} \mathrm{C}$ (Kotas et al., 2018). The inlet and detector temperatures were 250 and $300{ }^{\circ} \mathrm{C}$, respectively. The results were processed by Chromeleon 7.2. PLFAs with $<12 \mathrm{C}$ and $>20 \mathrm{C}$ atoms were excluded from the analysis of soil microbial communities, as were PLFAs with less than $0.5 \%$ of the total in peak area. The responses from all the remaining PLFAs were summed to obtain the total PLFA biomass (nmol g ${ }^{-1}$ of dw soil). Grouping according to the main microbial taxa using indicative fatty acids was performed according to (Johansen and Olsson, 2005; Willers et al., 2015).

\subsection{Evaluation of microbial responses}

To interpret the response of microbial communities to pharmaceutical exposure, we plotted basal respiration in relation to microbial biomass by applying graphical vector analyses with the non-amended conditions (control, 1, 13 and $61 \mathrm{~d}$ ) as a reference according to a proposed "microbial metabolic quotient" (Weetman and Fournier, 1982; Anderson and Domsch, 1985; Gielen et al., 2011). The response of a microbial community to pharmaceutical exposure was adapted from (Gielen et al., 2011) and analysed as the ratio of the mean values $(n=3)$ of soil basal respiration to microbial biomass (total PLFA). A greater distance from the intersect (non-amended controls) indicated a greater disturbance and development of the microbial community, whereas the direction of the vector (and thus quadrant) qualified the type of 
response. Positive responses of both respiration and biomass were interpreted as a stimulatory effect on the microbial community, a positive response for respiration and a negative response for biomass were indicative of a microbial community under stress, negative responses for both respiration and biomass suggested an inhibitory effect that seriously affected the microbial community and its function, and a negative response for respiration and positive for biomass were indicative of dormancy or a maintenance state of the microbial community.

\subsection{Statistics and microbial response analysis}

Two- and three-way ANOVAs were used to determine the significant difference between paired means (pharmaceuticals concentration in the soil, basal respiration and PLFA biomass and relative abundance of microbial groups in mol\%) according to many similar studies, e.g., (Gutiérrez et al., 2010; Srinivasan and Sarmah, 2014; Cycoń et al., 2016). This statistical method was also used to perform univariate analysis of the PLFA data to compare the total PLFA biomass and the PLFA biomass of selected groups among the soil samples and pharmaceutical treatments. The post hoc Tukey test was then used to identify differences in all possible pairs of means. To evaluate the overall patterns in the PLFA composition among samples, multivariate analyses (MANOVA) of all PLFAs were conducted to determine the variation attributable to the factors being tested. Principal component analysis (PCA) of the PLFA profiles was used to describe the changes in the microbial community structure after different exposure times during exposure to various treatments. Linear models were also used to study the effects of the treatment on PLFA biomass, microbial group abundance, and B/F and G+/G- ratios. The relative PLFA data (mol\%) were log-transformed in all statistical tests. Statistical analysis was performed in $R$ ( $R$ Development Core Team 2011) using the packages vegan, multcomp, factoextra and FactoMineR (Hothorn et al., 2008; Lê et al., 2008; Oksanen et al., 2019).

\section{Results}

\subsection{Residual concentrations of pharmaceuticals}

After being amended to soils as a single compound or in a mixture, the residual concentrations of parent pharmaceutical compounds showed decreasing trends during the exposure time (Fig. 1, SI-4). The degradation half-lives $\mathrm{DT}_{50}$ are provided in SI-2. It should be noted that these $\mathrm{DT}_{50}$ values were estimated from only 4 residual concentrations during the exposure time. To better determine the degradation rates of different compounds, residual concentrations over time should be analysed more frequently. When applied solely after pharmaceutical exposure for $\mathbf{1} \mathbf{d}$, the residual concentrations ranged between 71 and $100 \%$ for sulfamethoxazole in Phaeozem and Cambisol H, followed by citalopram in Cambisol H, irbesartan in Luvisol, clindamycin in Luvisol and Cambisol H (Fig. 1, SI-4). Carbamazepine and fexofenadine in the various soils showed less to negligible degradation. On $13 \mathbf{d}$, the residual concentration of sulfamethoxazole ranged from 8 to $32 \%$, and the lowest and highest values were for Phaeozem and Arenosol, respectively, indicating the highest degradation potential among the studied compounds. The lowest degradation potential was observed for carbamazepine, which ranged from 67 to $97 \%$, with the highest residual concentration in Phaeozem and the lowest in Arenosol (Fig. 1, SI-4). Fexofenadine displayed a degradation ranging from 29 to $95 \%$ and irbesartan from 41 to $78 \%$ depending on the soil type. On $61 \mathrm{~d}$, the relative concentrations of sulfamethoxazole and clindamycin were close to 0 , but the relative concentrations of carbamazepine and citalopram were degraded by less than $50 \%$ regardless of the soil type. Irbesartan was degraded on average by $80 \%$, while fexofenadine degradation differed among the soil types, with residual concentrations close to 0 in Phaeozem and Chernozem S but 38\% in Chernozem $\mathrm{H}$ and over $60 \%$ in Arenosol (Fig. 1, SI-4).

In addition to the parent compounds, five degradation products (metabolites) were found for the seven analysed (Fig. 1), two for carbamazepine and one for citalopram, clindamycin and sulfamethoxazole. Despite the possible existence of two acetyl sulfamethoxazole metabolites, only NAT-SMX (N4-acetyl sulfamethoxazole) was detected at the
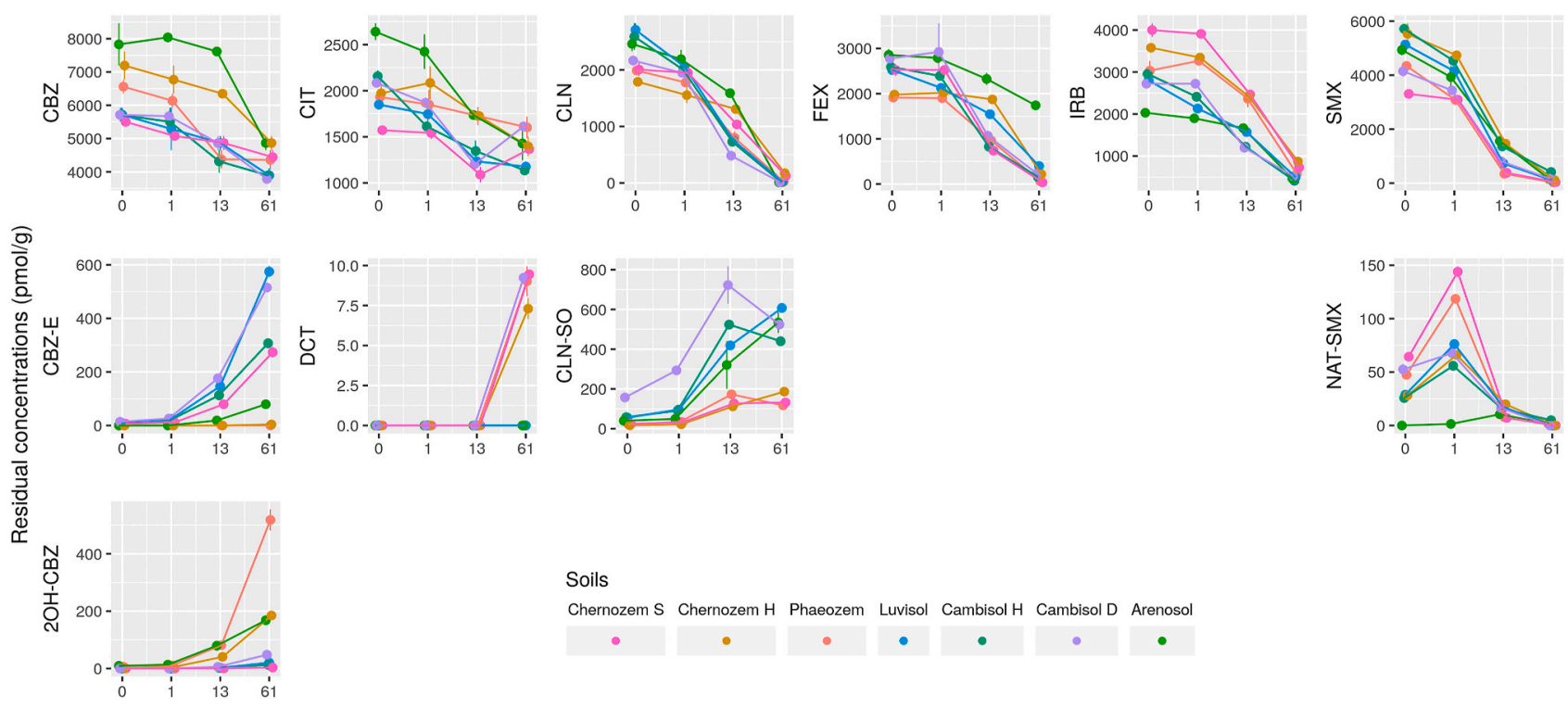

Incubation time (d)

Fig. 1. Residual concentrations of pharmaceuticals when applied to soils solely: first line displays parent compounds (carbamazepine, citalopram, clindamycin, fexofenadine, irbesartan and sulfamethoxazole), following lines show their metabolites (carbamazepine 10,11-epoxide/CBZ-E, trans-10,11-dihydro-10,11-dihydroxy carbamazepine/2OH-CBZ, N-desmethylcitalopram/DCT, clindamycin sulfoxide/CLN-SO, N4-acetyl sulfamethoxazole/NAT-SMX) as arithmetic mean ( $\mathrm{n}=3 / 2$ ), error bars stay for standard deviation. Incubation time is presented as an ordinal variable. Different colours represent studied soils. (For interpretation of the references to colour in this figure legend, the reader is referred to the Web version of this article.) 
highest concentration in Chernozem S and Phaeozem and the lowest concentration in Arenosol. Compared with other observed metabolites, NAT-SMX formation started immediately after soil was spiked with the sulfamethoxazole solution, with the maximum concentration reached on $1 \mathrm{~d}$ and rapid degradation over $13 \mathrm{~d}$ in most soils except Arenosol, for which the maximum concentration was reached on $13 \mathrm{~d}$ regardless of individual or mixture application (SI-5). Complete degradation of sulfamethoxazole was observed in all soils on $61 \mathrm{~d}$. The concentration of CLN-SO (clindamycin-sulfoxide) started to increase in Luvisol, both Cambisols and Arenosol on $1 \mathrm{~d}$, reaching the maximum value on 13 $\mathrm{d}$ and remaining persistent during the study period.

When applied as the pharmaceutical mixture, the half-life of pharmaceuticals (SI-2) slightly increased for most of the compounds. The residual concentration showed comparable trends as it was observed for the single application. The lowest values of the relative concentration were observed for sulfamethoxazole and the highest values for carbamazepine and citalopram (SI-5). Accordingly, the rate of metabolite formation decreased (SI-5). In addition, in the case of clindamycin, when applied solely, the highest formation of CLN-SO was observed in Cambisol D; when applied in a mixture, formation in this soil decreased to one-quarter, while the highest formation was observed in Chernozem S. The opposite result was observed for sulfamethoxazole and the formation of NAT-SMX, in which the highest detection was occurred in Chernozem S when applied alone and in Cambisol D when applied in a mixture (SI-5).

\subsection{Microbial biomass and community profile shifts in treated soils}

Microbial biomass varied between the soils and was particularly affected by the exposure time (Fig. 2A; SI-6, SI-7). Principal component analysis (PCA) separated PLFA data into two principle components (PCs), where PC1 (exposure time) explained $39-73 \%$ of the variation in the community composition (Fig. 3). Under the initial conditions, the level of total PLFA ranged from $51( \pm 13)$ to $241( \pm 16) \mathrm{nmol} \mathrm{g}^{-1} \mathrm{dw}$ soil, with the lowest PLFA biomass corresponding to Arenosol, followed by Chernozem H (73 \pm 25$)$, Luvisol (131 \pm 35$)$, Cambisol D (142 \pm 5$)$, Phaeozem $(144 \pm 5)$, and Chernozem $S\left(177 \pm 4 \mathrm{nmol} \mathrm{g}^{-1} \mathrm{dw}\right.$, respectively; means \pm standard deviation), and the highest PLFA biomass for Cambisol H (Fig. 2A). Bacteria prevailed in all soils with a minor portion of the other microbial groups (Fig. 2A,B, SI-6). The G+/Gratio was $\leq 1$ and was higher in Arenosol and Cambisol $H$ than in the other studied soils and lowest in Chernozem $\mathrm{S}$. The $\mathrm{B} / \mathrm{F}$ ratio was between 6.2 (Arenosol) and 29.5 (Chernozem $\mathrm{H}$ ) in relation to the different qualities of the studied soils (Fig. 2B, SI-6).

On $1 \mathrm{~d}$, no consistent difference was observed in the soil microbial community profiles among the various treatments and soils, as also supported by the PCA results (Fig. 3). On 13 d, however, a significant increase in biomass (22-85\%) was observed in all soils. The highest PLFA biomass was predominantly observed in Cambisol $\mathrm{H}$ regardless of the treatment, with the highest value of $322 \mathrm{nmol} \mathrm{g}^{-1}$ for the control, while the lowest PLFA biomass was found for all treatments in Arenosol, ranging between 36 and $87 \mathrm{nmol} \mathrm{g}^{-1}$ from citalopram to the control, respectively (Fig. 2A). The $\mathrm{G}+/ \mathrm{G}$ - ratio decreased in some soils and
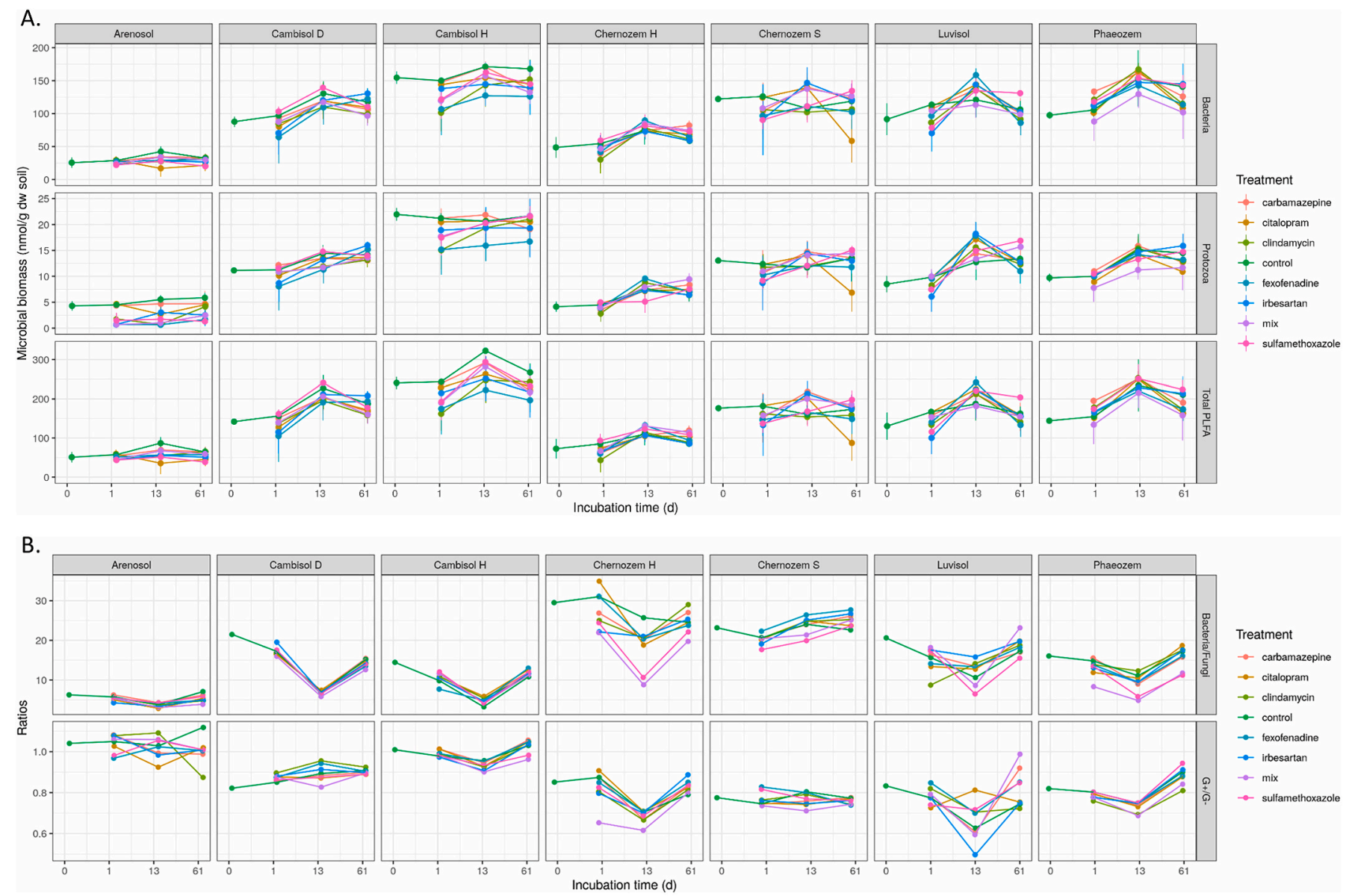

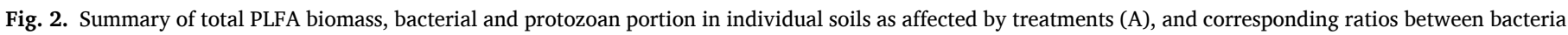

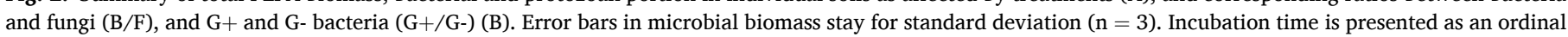

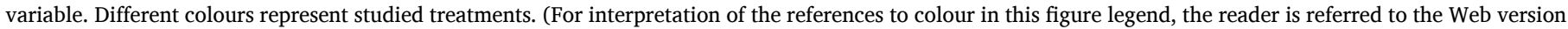
of this article.) 


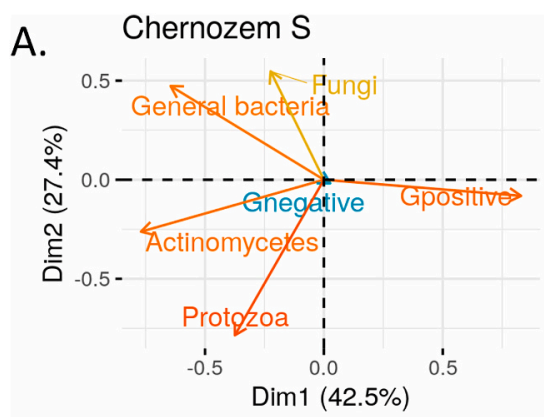

Luvisol

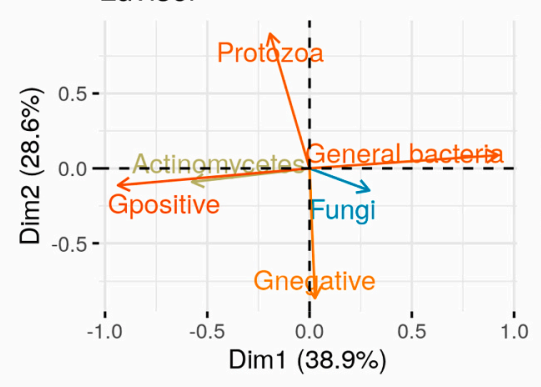

Arenosol

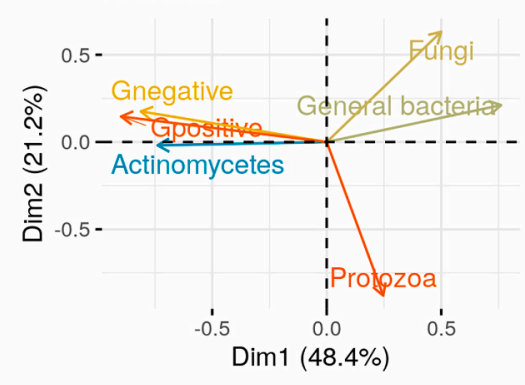

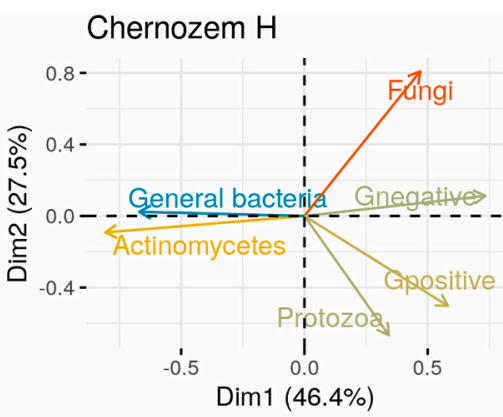

Cambisol $\mathrm{H}$

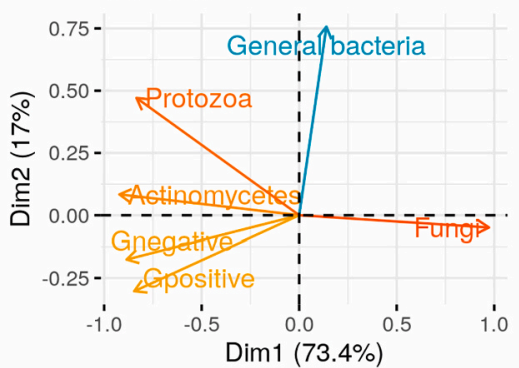

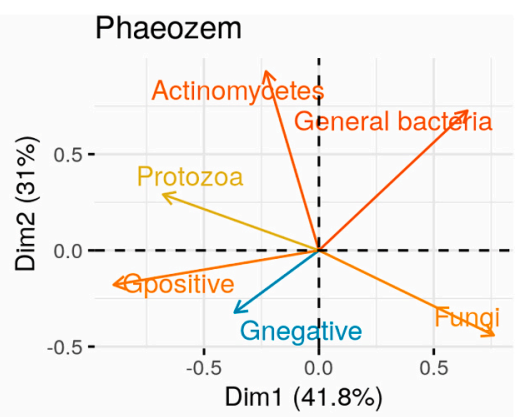

Cambisol D

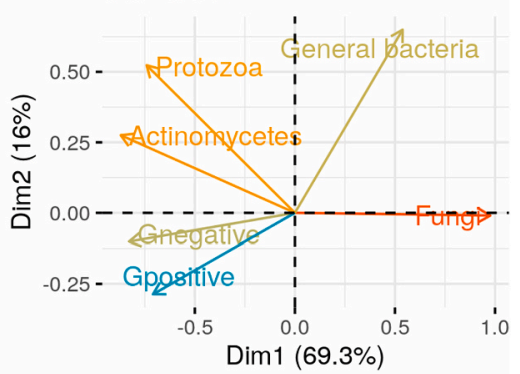

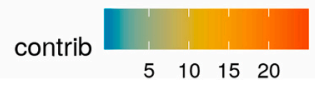

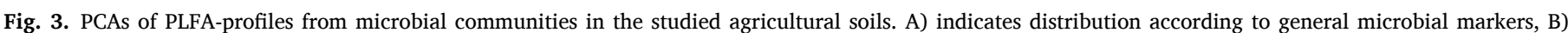

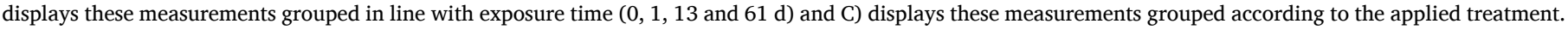

treatments, especially in Luvisol ( 0.5 for irbesartan, 0.6 for carbamazepine and mixture) and slightly increased in Arenosol to 1.1 for both antibiotics and mixture treatments (Fig. 2B). A general drop in the B/F ratio was detected after $13 \mathrm{~d}$ in all soils, ranging between 2.8 for citalopram in Arenosol and 26.4 for fexofenadine in Chernozem S. PCA revealed clear trends towards a fungal community in Chernozem $\mathrm{H}$ and Phaeozem when amended with the sulfamethoxazole or pharmaceutical mixture (Fig. 3). A similar, nonetheless smaller, trend was also observed in Luvisol (along with Chernozem $\mathrm{H}$ and Phaeozem, all soils derived from loess parent material), while the effect of the treatments in other soils was insignificant (Fig. 3). On $\mathbf{6 1} \mathbf{~ d}$, a small decline in biomass was observed (Fig. 2A), with the highest detected biomass in the control of Cambisol H $\left(267 \mathrm{nmol} \mathrm{g}^{-1}\right)$ and the lowest in Arenosol amended with sulfamethoxazole and citalopram ( 39 and $45 \mathrm{nmol} \mathrm{g}^{-1}$ ). PCA revealed a general shift towards a protozoan community (Fig. 3).

Bacterial PLFA significantly decreased in Phaeozem after being amended with the mixture of pharmaceuticals and in Cambisol $\mathrm{H}$ after all pharmaceutical amendments. The treatment had a low $(\sim 1 \%)$ but significant effect on the community composition across soils (SI-7). However, the effect of the treatments was apparently higher in distinct soils (SI-8). The abundance of Actinomycetes increased after citalopram or clindamycin exposure in Cambisol $\mathrm{H}$ and after sulfamethoxazole exposure in Cambisol D. In contrast, the abundance of Actinomycetes decreased after pharmaceutical mixture in Chernozem S and Phaeozem.
Fungi responded to the pharmaceutical mixture in Phaeozem and Arenosol, in which their abundance increased. Conversely, fungi were negatively affected by all the pharmaceutical compounds and their mixture in Cambisol H. Protozoa responded positively to citalopram, irbesartan, sulfamethoxazole, and the pharmaceutical mixture in Cambisol $\mathrm{H}$ and to clindamycin in Cambisol $\mathrm{H}$ and Chernozem S. Negative effects of clindamycin, fexofenadine, sulfamethoxazole and pharmaceutical mixture on protozoa were observed in Arenosol. Microbial community shifts affected by the pharmaceuticals were reflected by changes in the $\mathrm{B} / \mathrm{F}$ and $\mathrm{G}+/ \mathrm{G}$ - ratios. In particular, the $\mathrm{B} / \mathrm{F}$ ratio decreased in response to sulfamethoxazole and pharmaceutical mixture amendments in both Chernozem $\mathrm{H}$ and Phaeozem. In addition, the pharmaceutical mixture decreased the $\mathrm{B} / \mathrm{F}$ ratio in Cambisol $\mathrm{D}$ and Arenosol and negatively affected the G+/G- ratio in Chernozem $\mathrm{H}$, Phaeozem, and Cambisol H. Similarly, clindamycin decreased the G+/ G- ratio in Phaeozem because of the decline in G+ bacteria. Shifts in the microbial community composition were most pronounced on $13 \mathrm{~d}$ and persisted long term (to $61 \mathrm{~d}$ ) in most cases. The details of the pairwise comparisons between the treatments and controls in the given soil were significant at $p<0.05$ and are shown in SI-9.

\subsection{Basal respiration}

On $1 \mathbf{d}$, an overall increase in basal respiration was observed in 

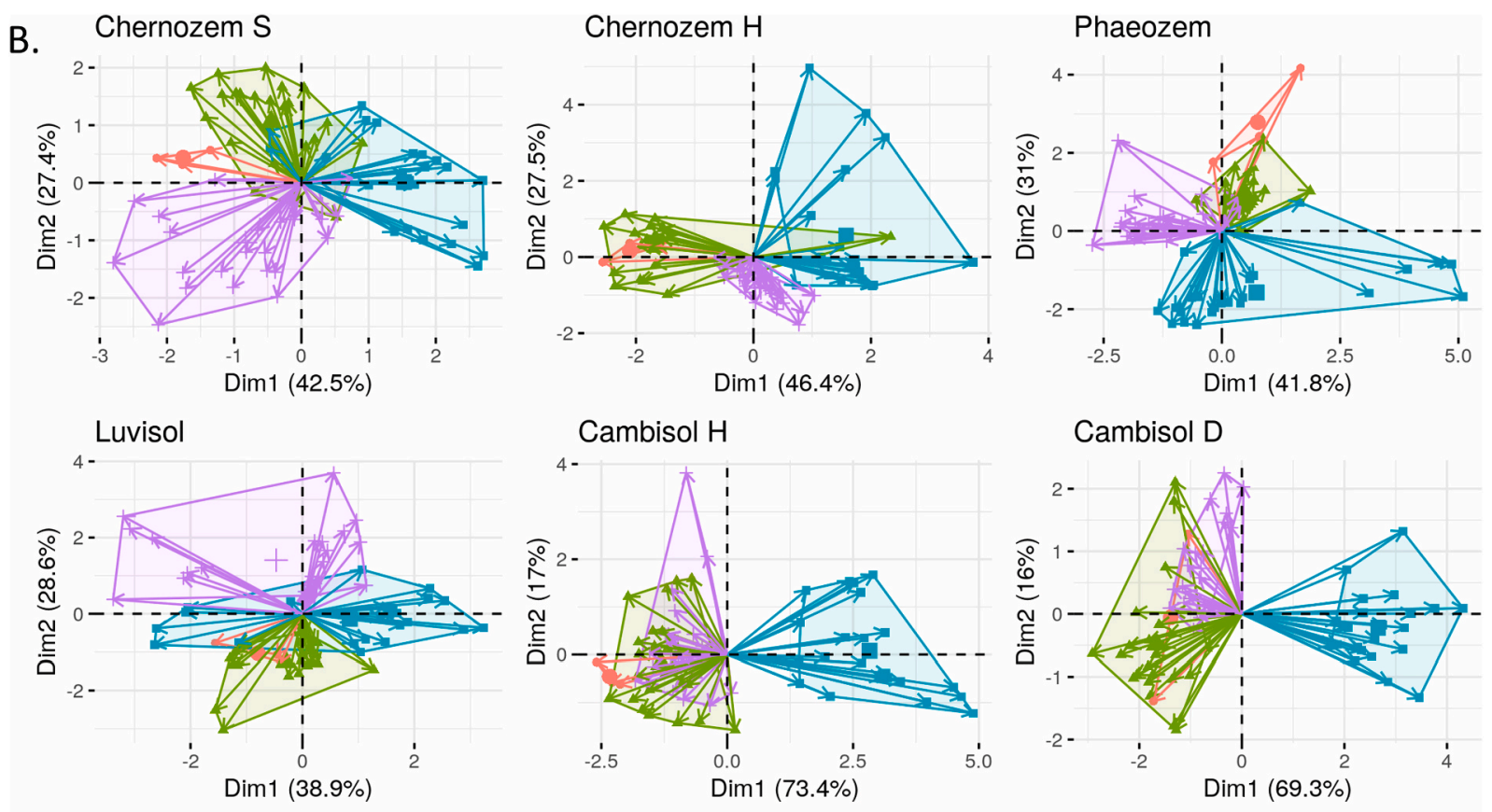

\section{Cambisol D}

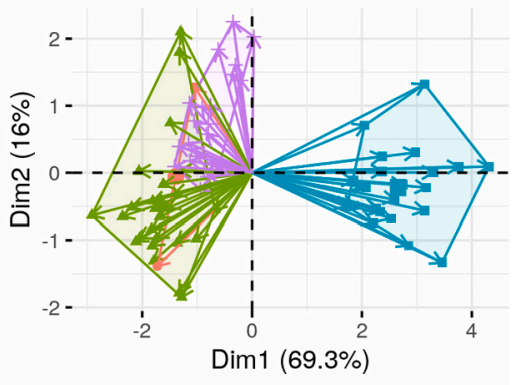

Arenosol

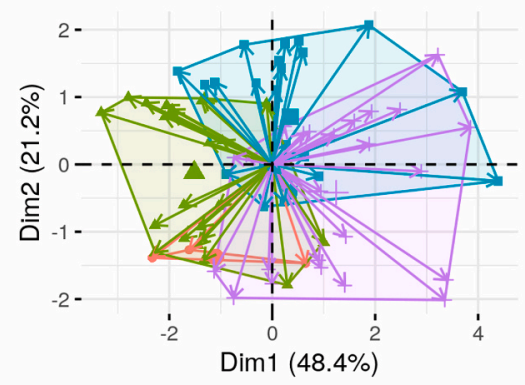

Time $\rightarrow \Rightarrow 1 \rightarrow 13 \rightarrow 61$

Fig. 3. (continued).

Chernozem S regardless of the treatment, in Phaeozem (except fexofenadine) and in Cambisol D (except citalopram and clindamycin). In contrast, a general decrease in respiration was found in Luvisol and Cambisol $\mathrm{H}$ for all treatments except the control, Chernozem $\mathrm{H}$ (except control, carbamazepine and irbesartan) and Arenosol (except fexofenadine and irbesartan). Compared with the control, basal respiration significantly dropped in Phaeozem when amended with sulfamethoxazole or the pharmaceutical mixture. Still, compared to the initial conditions, an increase in basal respiration was pronounced in all treatments in Chernozem H, Phaeozem and Arenosol, and Cambisol D (except when amended with the pharmaceutical mixture) on $\mathbf{1 3} \mathbf{~ d}$. In Chernozem S, respiration increased in response to clindamycin, irbesartan and sulfamethoxazole along with the control, while it decreased in response to carbamazepine, citalopram and mixture treatments. No increase in respiration was confirmed for Luvisol and Cambisol $\mathrm{H}$, including the control treatment. On $\mathbf{6 1} \mathbf{d}$, the differences in respiration as affected by treatment were not significant $(p>0.05)$. A general decrease in respiration was observed in Chernozem $S$, Luvisol and both Cambisols, while a decrease in respiration was found in Chernozem $\mathrm{H}$ only with clindamycin and fexofenadine, the Phaeozem control and when amended with carbamazepine, fexofenadine, irbesartan and mixture, and Arenosol with citalopram. Based on microbial community biomass and basal respiration, we obtained different types of responses to pharmaceutical exposure (Fig. 4) that are further explored in the Discussion.
According to the three-way ANOVA results, basal respiration was shown to be significantly affected by treatment $(p<0.001)$ as a single factor as well as by the interaction with exposure time and soil (SI-7). Respiration was shown to be particularly affected by the interaction among all three factors, which explained $25.4 \%$ of the variance, as well as the interaction between soil and treatment and between time and treatment; however, these factors explained only $9.9 \%$ and $6.6 \%$ of the variance, respectively, while the effect of treatment as a single factor explained only $1 \%$ of the variance in basal respiration.

\section{Discussion}

Degradation of all the examined pharmaceuticals with the simultaneous formation of several metabolites was detected in all the studied soils, but varied depending on the soil type and pharmaceuticals (Fig. 1). Considering that the degradation of pharmaceuticals in soil is governed by microbial activity (Lin and Gan, 2011; Löffler et al., 2005; Radke et al., 2009; Srinivasan and Sarmah, 2014; Zhang et al., 2017), these variations can be explained by the different time-dependent microbial responses to the applied treatment within specific soil properties. The assessment is rather qualitative and based on the method described by (Gielen et al., 2011). 

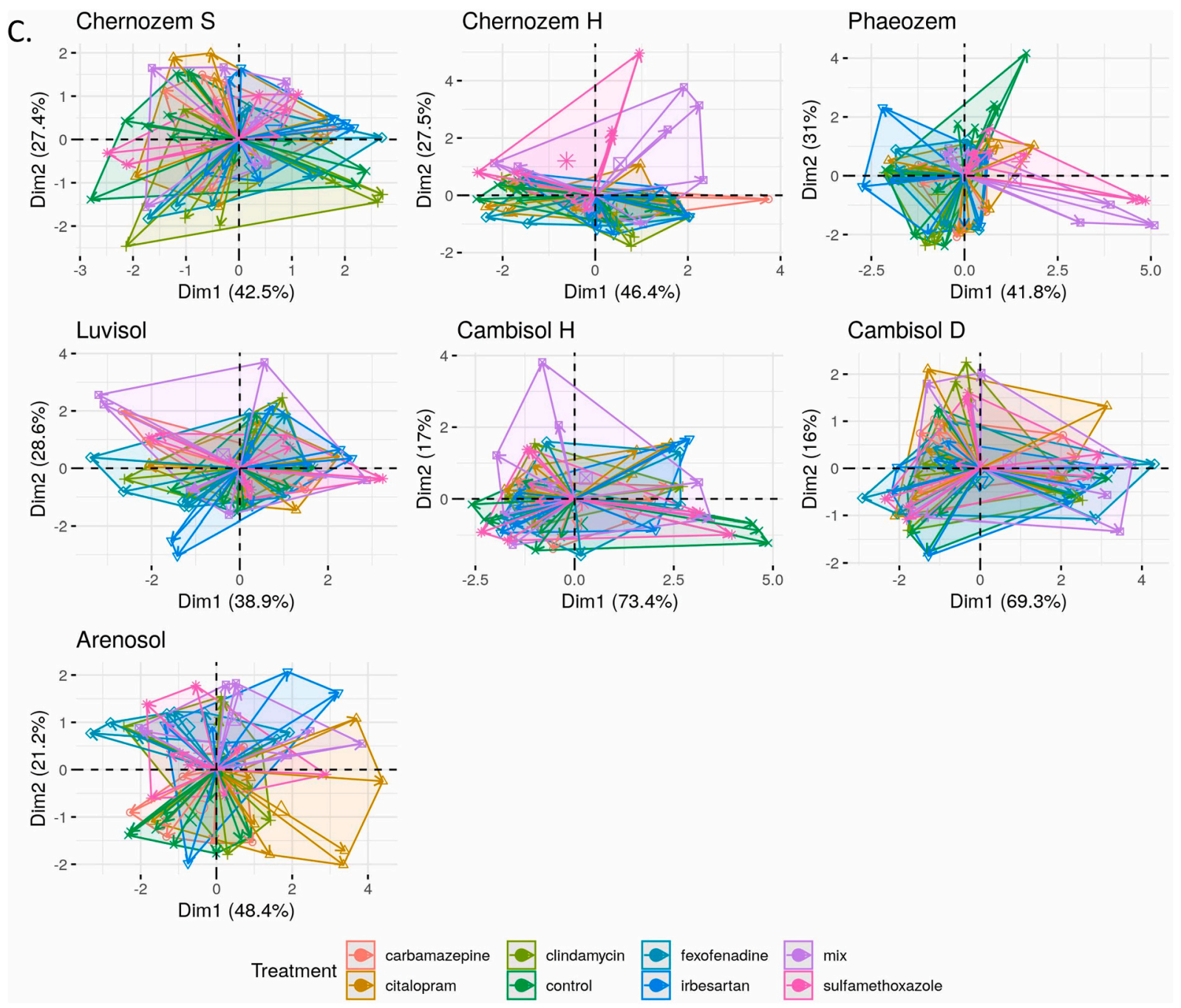

Fig. 3. (continued).

\subsection{Stimulatory effect of pharmaceuticals on respective microbial communities}

The increase in basal respiration relative to the non-amended condition (controls) was indicative of enhanced mineralization of carbon sources to $\mathrm{CO}_{2}$ for energy production, whereas the increased microbial biomass was indicative of the conversion of carbon sources into biomass and thus growth (Brown et al., 2004). A stimulatory effect was found in some soils amended with sulfamethoxazole (Cambisol D, Luvisol, Phaeozem, Chernozem H and S), clindamycin (Arenosol and Phaeozem), fexofenadine (Chernozem H), irbesartan (Phaeozem and Chernozem S), citalopram (Chernozem H) (Fig. 4). In the case of sulfamethoxazole this phenomenon might be explained by the low sorption potential, particularly in Phaeozem, Chernozems $\mathrm{H}$ and $\mathrm{S}\left(\mathrm{k}_{\mathrm{f}}\right.$ values of $0.57,0.88$ and 0.64 , respectively, SI-2). Sulfonamides are fairly water soluble and polar; thus, soil sorption is a pH-related process, decreasing with increasing pH (Boxall et al., 2002; Koba et al., 2016). Weak sorption of sulfamethoxazole onto soil and thereby its high mobility and bioavailability has been shown in silty clay, clay loam and silty clay loam soils with $\mathrm{pH}\left(\mathrm{CaCl}_{2}\right.$ ) ranging from 4.5 to 6.9 (Höltge and Kreuzig, 2007; Liu et al., 2010) and previously in the same set of soils (Kodešová et al., 2016, 2015). Additionally, biodegradation has been shown to be the predominant mechanism of sulfamethoxazole degradation in clay loam soil ( $\mathrm{pH}\left(\mathrm{CaCl}_{2}\right)$ 4.9, TOC $13.5 \mathrm{~g} \mathrm{~kg}^{-1}$ ) (Liu et al., 2010). In our case, Phaeozem and Chernozem S showed the highest production of NAT-SMX
(Fig. 1), likely confirming the degradation and low sorption of sulfamethoxazole.

Luvisol had relatively low sorption potential $\left(\mathrm{k}_{\mathrm{f}}\right.$ value of 1.28 , SI-2) suggesting the similar process as explained for Phaeozem and Chernozem S. Interestingly, stimulation was detected in Cambisol D, but only immediate to short-term ( 1 and 13 d, Fig. 4), which could be explained by a delay in sorption of the antibiotic.

The effect of application of the mixture on the microbial community displayed similar patterns to sulfamethoxazole (Figs. 3 and 4) despite the minor differences between single and mixture amendments found for pharmaceutical degradation (Fig. 1, SI-4). We suggest that this result could be due to the more pronounced and distinct effect of sulfamethoxazole on the microbial community than that of the other studied compounds (Fig. 3). However, such similar stimulation effect was only observed in Chernozem H (13 and $61 \mathrm{~d}$ ) and Chernozem S (61 d). More detailed research is planned to identify this phenomenon.

Along with the increase in microbial biomass, a short-term response (13 d) to the pharmaceutical mixture resulted in shifts in the microbial community; the decrease in the $\mathrm{B} / \mathrm{F}$ ratio altered the microbial community towards fungi in Chernozem $\mathrm{H}$, Phaeozem, Cambisol D and Arenosol, while the decrease in the G+/G- ratio indicated a negative impact on the $\mathrm{G}+$ bacteria in Chernozem $\mathrm{H}$, Phaeozem, and Cambisol $\mathrm{H}$ (Fig. 2B, SI-8). Similarly, sulfamethoxazole decreased the B/F ratio in Chernozem $\mathrm{H}$ and Phaeozem. The decrease in the $\mathrm{B} / \mathrm{F}$ ratio was often associated with a stimulatory effect on the soil microbial community. 

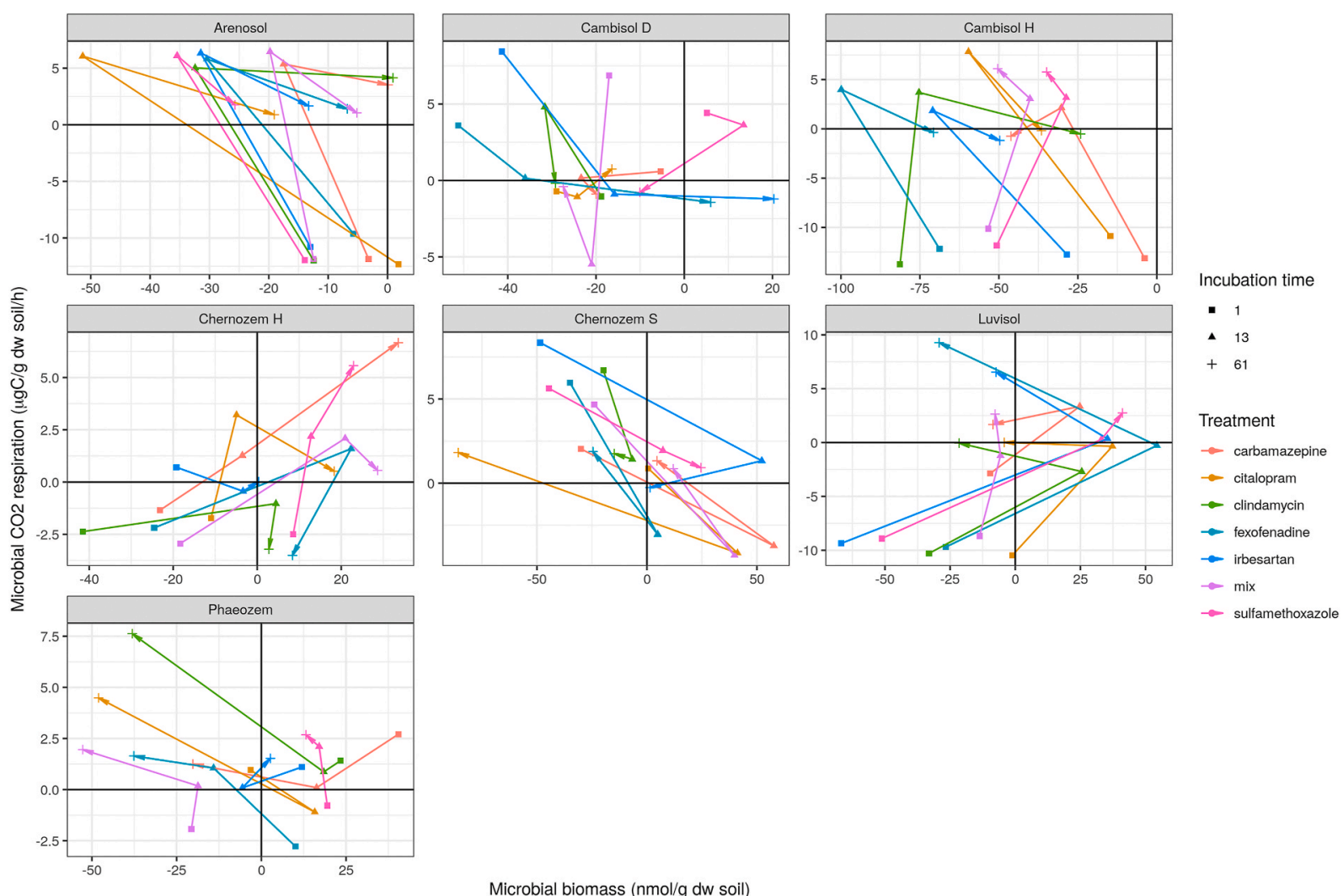

Microbial biomass (nmol/g dw soil)

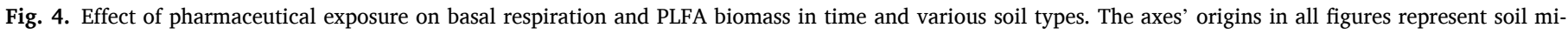

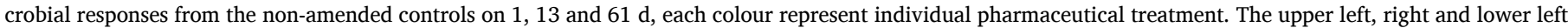

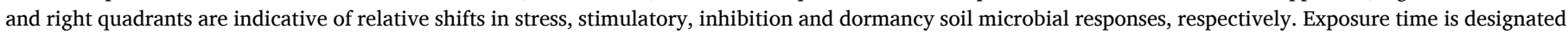

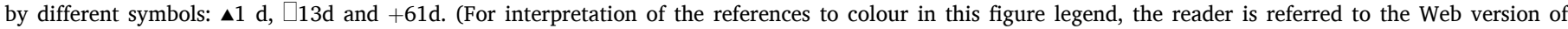
this article.)

Stimulation of the fungal biomass may indicate enhanced degrading activity of fungal members of the community, e.g., through the production of extracellular laccases and peroxidases (Chen et al., 2016). Similar community shifts caused by sulfamethoxazole amendment have only been reported for a loamy sand soil ( $\mathrm{pH} 6.6, \mathrm{C}_{\text {org }} 0.86 \%$ ), resulting in alterations towards G- bacteria and an increased proportion of fungal biomass (Gutiérrez et al., 2010). Tentative explanations for this phenomenon could be a gradual increase in the resistance of a number of bacterial species in the environment (Fahrenfeld et al., 2014; Goodman and Gilman, 2011; Heuer et al., 2008) and that plasmid-mediated resistance may be possessed to a greater extent by G- bacteria (Stokes and Gillings, 2011).

The stimulatory effect of the other antibiotic, clindamycin, promoted substantial changes in the microbial community composition only in Phaeozem, where exposure to clindamycin revealed $\mathrm{G}+/ \mathrm{G}-$ ratio declines while maintaining the same $\mathrm{B} / \mathrm{F}$ ratio. The reduced $\mathrm{G}+/ \mathrm{G}-$ ratio and thus enhanced abundance of G- bacteria at the extent of G+ bacteria persisted over the long-term ( $61 \mathrm{~d}$, Phaeozem). These results suggested, first, that clindamycin has a lower bacterial inhibitory effect than sulfamethoxazole, as shown for other sulfonamide antibiotics (Majewsky et al., 2014). Second, clindamycin may lose antibacterial activity via sorption (Kümmerer, 2009). Considering its pKa of 7.7, clindamycin exists predominantly as a cation in acidic environments and as a neutral species when introduced into basic soil. Earlier studies (Porubcan et al., 1978; Kodešová et al., 2016) described a strong interaction of clindamycin with clay by cation exchange mechanisms at $\mathrm{pH}$ values favouring the cationic form of clindamycin. However, in other research, the mobility of clindamycin in the soil profile was limited despite $\mathrm{pH}<7$ and the very low amounts of clay (8.4\%), organic carbon (1.6\%) and CEC (14.3 $\left.\mathrm{cmol} \mathrm{kg}^{-1}\right)$, suggesting that a retaining mechanism other than cation exchange might be relevant (Koba et al., 2017; Kodešová et al., 2015; Wu et al., 2010; Schmidtová et al., 2020). In our study, the rapid decline in clindamycin concentration was accompanied by the formation of clindamycin sulfoxide (CLN-SO; up to $35 \%$ on 13 d, Fig. 1, SI-5) with the lowest concentrations in Chernozems (Chernozem $S$ and Chernozem $\mathrm{H}$; better quality soils with higher organic content, microbial biomass and $\mathrm{pH}$ ), suggesting a rapid transformation into some minor metabolites in these soils (Koba et al., 2017), possibly via microorganisms. To our knowledge, thioester oxidation (forming clindamycin-SO) as a proof of biodegradation has been reported only for wastewater-derived microbial communities (Ooi et al., 2017; Zumstein and Helbling, 2019).

The low bioavailability of citalopram, described here by its pKa and $\mathrm{k}_{\mathrm{f}}$ values $(\mathrm{SI}-1,2)$, reflects the importance of cation binding in all the studied soils with a predicted sorption behaviour. The stimulation was only observed in Chernozem $\mathrm{H}$ (better-quality soil, well-structured and with higher nutrient availability). In addition, N-demethylation of citalopram and the corresponding formation of N-desmethylcitalopram (DCT) was also detected only in the long-term (61 d) at very low concentrations (Fig. 1, SI-4), supporting the theory that within the exposure time, citalopram was mostly inaccessible to the soil microorganisms.

Limited removal of carbamazepine in soils is also more associated with sorption phenomena than with biodegradation, as other authors have already observed (Kodešová et al., 2015; Löffler et al., 2005; Martínez-Hernández et al., 2016; Tiehm et al., 2011; Williams et al., 2006; Schmidtová et al., 2020), and noted that carbamazepine sorption is mainly controlled by the organic carbon content. Nevertheless (Martínez-Hernández et al., 2016), suggested the occurrence of carbamazepine 10,11-epoxide (CBZ-E) as a proof of enzymatic function and biodegradation. In addition, the biological transformation of 
carbamazepine in a loamy sand soil ( $\mathrm{pH} 7.7,1.4 \% \mathrm{C}_{\text {org }}$ ) was shown to be the only mechanism with a significant ability to form trans-10, 11-dihydro-10,11-dihydroxy carbamazepine (2OH-CBZ) (Löffler et al., 2005). This metabolite slowly increased in our study (detected on 13 and $61 \mathrm{~d}$ ), although only in a few soils, mainly Phaeozem, followed by Chernozem $\mathrm{H}$ and Arenosol. While, the stimulation was not observed in Arenosol, short-term stimulation by carbamazepine was found in Luvisol (13 d) and Phaeozem (1 and 13 d) (Fig. 4), suggesting that a microbial contribution to carbamazepine transformation cannot be excluded. Stimulation in Chernozems $\mathrm{H}$ and S amended with carbamazepine was only detected on $61 \mathrm{~d}$, likely suggesting the recovery response in these nutrient-rich soils and ability to process the compound and its metabolites. Additionally, we hypothesize that biodegradation would continue if incubated for a longer period, thereby confirming its slow elimination regardless of the soil type (Koba et al., 2016; Thelusmond et al., 2019). In the case of 2OH-CBZ, the presence of two neighbouring hydroxyl groups suggested ring cleavage by relevant bacteria, considering that only $<10 \%$ of carbamazepine was transformed into metabolites. Finally, the concentrations of $2 \mathrm{OH}-\mathrm{CBZ}$ and CBZ-E did not decrease during the exposure time, showing a continuous upward trend. This phenomenon could indicate that the enzymes responsible for the transformation of carbamazepine are probably not common in agriculture soils, as recently proposed by the lack of impact on the microbial metabolic pathways involved in biodegradation and the limited removal of carbamazepine (Thelusmond et al., 2016, 2018). The low $\mathrm{k}_{\mathrm{f}}$ value further suggested the bioavailability of carbamazepine to certain bacteria in soil. Previously (Thelusmond et al., 2018), noted that some phylotypes (Actinobacteria, Rhizobiales, Gammaproteobacteria) appear to benefit from carbamazepine application to soil (three sandy loam soils of $\mathrm{pH} 6.9$, with $2.8 \%$, $2.4 \%, 1.4 \% \mathrm{C}_{\text {org }}$, and one loamy sand soil of $\mathrm{pH} 6.6,1.9 \% \mathrm{C}_{\text {org }}$ ) and that the effect of carbamazepine on the soil microbial community likely decreases with time.

The number of studies on fexofenadine and irbesartan metabolites and the enzymes responsible for their biodegradation is limited. Based on the $\mathrm{pKa}$ and soil $\mathrm{pH}$ values, fexofenadine was in the zwitterionic form in all the studied soils, having both positive and negative charges. Excluding Luvisol and Arenosol, almost all fexofenadine was degraded within the exposure time, with little differences among mixed and individual applications. Since these two soils were the poorest in terms of microbial biomass, organic carbon and CEC perspective (SI-1, SI-2), we may expect limited removal mechanisms by these efforts. Short-term stimulation of microbial community in Chernozem $\mathrm{H}$ (13 d) may suggest possible microbial uptake. Irbesartan was found to be degraded in wastewater-activated sludge (Boix et al., 2016; Shah et al., 2010), with $25-30 \%$ removal obtained in 35 days. In addition, five metabolites were identified as a result of irbesartan hydroxylation, hydrogenation, oxidation or dealkylation in different parts of the molecule (Boix et al., 2016). In our study, irbesartan concentrations significantly decreased within the exposure time regardless the soil or application in the mixture. Immediate and long-term stimulation was observed in Phaeozem and short-term in Chernozem S (Fig. 4). Based on the physical chemical properties of irbesartan, its neutral or anionic characteristics, low sorption potential in these soils (SI-2), and therefore its bioavailability, it can be speculated that this removal mechanism was also supported by microorganisms. The detection of fexofenadine and irbesartan metabolites is beyond the scope of this study. Since the behaviour of these pharmaceuticals in soils is still unclear and only limited reports have examined their fate, a complex analytical and molecular study mapping possible metabolic pathways should be performed.

\subsection{Stress effect of pharmaceuticals on respective microbial communities}

Microbial communities demonstrating insufficient nutrients to form new microbial biomass while creating more energy through increased respiration indicated a stress effect of pharmaceuticals (Gielen et al., 2011; Rui et al., 2016). All the investigated pharmaceuticals imposed a degree of stress on soil microbial communities (each of them in at least one soil, Fig. 4). The immediate stress response (1 d) was observed for all pharmaceuticals in Chernozem $S$ and was associated with the increase of protozoan PLFA (Figs. 2A and 3, SI-8). The stress response on all pharmaceuticals was observed in Arenosol on 13 and $61 \mathrm{~d}$ (except clindamycin, $61 \mathrm{~d}$ ). These findings could be explained mainly by the apparent low microbial biomass associated with a low resilience capacity of its microbial community due to nutrient limitations. The short-term stress effect was also found in Cambisol $\mathrm{H}$ on all treatments and remained until the long-term exposure in sulfamethoxazole and mixture treatments (Fig. 4), being replaced by inhibition in other pharmaceuticals. Interestingly, despite the low biodegradation capacity for carbamazepine, this pharmaceutical was able to provoke stress microbial responses in all soils (Fig. 4). Immediate ( $1 \mathrm{~d})$ stress response to carbamazepine was observed in Cambisol D and Chernozem S, which was previously reported only on $13 \mathrm{~d}$ at higher carbamazepine concentration $(1000 \mu \mathrm{g}$ $\mathrm{g}^{-1}$ ) in a sandy loam soil of pH 5.6 (Gielen et al., 2011). In some cases (clindamycin in Arenosol, irbesartan in Phaeozem and Chernozem S, carbamazepine in Chernozems $\mathrm{H}$ and $\mathrm{S}$, sulfamethoxazole and mixture in Chernozem S) stress response changed to stimulation indicating that microbial communities were able to mitigate stress responses to pharmaceuticals after a longer exposure time.

\subsection{Inhibitory effect of pharmaceuticals on respective microbial communities}

The concurrent decrease in microbial biomass and respiration, which indicated the inhibitory effect of pharmaceuticals on microbial community (Gielen et al., 2011), demonstrated unfavourable environmental conditions or a potentially toxic effect of pharmaceuticals (Zielezny et al., 2006). This effect was detected in all soils, except Chernozem S (Fig. 4). Immediate inhibition to all pharmaceuticals was found in soils with a lower organic content, i.e. Arenosol (except citalopram), Cambisol $\mathrm{H}$ and Luvisol (Fig. 4). While, the inhibition was replaced by stress under longer exposure (13 and $61 \mathrm{~d}$ ) in Arenosol, still, it was observed in Cambisol H on $61 \mathrm{~d}$ for most of pharmaceuticals (except sulfamethoxazole and mixture). In Cambisol $\mathrm{H}$, the overall drops in total PLFA biomass started immediately and was mostly pronounced when amended with fexofenadine and clindamycin. The subsequent alterations in microbial biomass in all treatments ( $13 \mathrm{~d}$ ) were accompanied by distinct changes in the community composition; the $\mathrm{B} / \mathrm{F}$ ratio decreased by half in all treatments with negligible alterations of the $\mathrm{G}+/ \mathrm{G}$ - ratio, and the protozoan PLFA significantly increased in response to both antibiotic treatments. Soil protist communities respond to anthropogenic perturbations; however, they are rarely included in ecotoxicological studies in soils (Geisen et al., 2018). Elevated protozoan populations have been detected in aquifers contaminated with aromatic hydrocarbons, suggesting that protists increased because of grazing on bacterial populations that accelerate nutrient turnover (Sinclair et al., 1993; Kota et al., 1999). An immediate inhibitory effect in Luvisol was mainly switched to stimulation and dormancy. An inhibitory response to antibiotics was pronounced in slightly acidic soils such as Cambisol $\mathrm{H}$ and Arenosol (Fig. 4, SI-2). A similar response was reported for a silt loam soil ( $\mathrm{pH} \mathrm{5.7,} \mathrm{TC} 18.2 \mathrm{~g} \mathrm{~kg}^{-1}$ ), where amendment with the antibiotic sulfamethoxazole at $7 \mu \mathrm{g} \mathrm{g}^{-1}$ resulted in a decrease in respiration within the first 2 days (Liu et al., 2009); furthermore, an inhibitory effect was observed in a sandy loam soil ( $\mathrm{pH} 7.6$, TOC $0.95 \%)$ at higher sulfamethoxazole levels $\left(>25 \mu \mathrm{g} \mathrm{g}^{-1}\right.$ ), while microbial biomass was significantly reduced at environmentally relevant concentrations (Molaei et al., 2017). After a short-term exposure (9 days), direct inhibition of bacterial growth has been previously reported in a loamy sand soil $\left(\mathrm{pH}_{(\mathrm{KCl})} 4.9,3.7 \% \mathrm{C}_{\text {org }}\right.$ ) by (Demoling et al., 2009), in which bacterial growth decreased with increasing sulfamethoxazole concentrations (0.1-1-20-500 $\mathrm{mg} \mathrm{kg}^{-1}$ soil). A long-term inhibitory effect of pharmaceuticals was observed in Cambisols, and occasionally in Luvisol and Chernozem H (Fig. 4). 


\subsection{Dormancy effect of pharmaceuticals on respective microbial communities}

In contrast, an increasing microbial biomass with respect to decreasing respiration suggests an antagonistic conversion or a dormancy and maintenance state of microbial communities (Anderson and Domsch, 1985; Gielen et al., 2011), which are usually higher for microorganisms adapted to a permanent input of available substrates rather than for microbial communities from nutrient-limited environments (Van Bodegom, 2007). Such a dormancy effect was mainly detected in better quality soils (e.g., Chernozems). All pharmaceuticals provoke dormancy effect at different exposure time. Immediate dormancy was found in Phaeozem and Chernozem $\mathrm{H}$ after sulfamethoxazole, but it was shortly replaced by stimulation, suggesting a high resilience of the microbial community to this amendment and strong capability of microbial community to recover respiration and biomass (Fig. 4). Immediate dormancy in Arenosol treated with citalopram, short-term dormancy in Luvisol treated with clindamycin, fexofenadine, irbesartan and citalopram, were replaced by stress and inhibition, and the long-term dormancy was found in Cambisol D amended with fexofenadine and irbesartan, suggesting that microbial communities in these soils were not able to recover from the negative effect of these pharmaceuticals. In addition to the low concentrations of total carbon and nitrogen, we can speculate that the capacity of these soils to sustain microbial productivity via promoting the minimum necessary nutrients decreased over time. Above described processes could also be valid for soils with a higher nutrient content, such as Phaeozem with fexofenadine and citalopram, Chernozem $\mathrm{H}$ with clindamycin and fexofenadine, and Chernozem S with fexofenadine, irbesartan and citalopram (Fig. 4). While this phenomenon could be explained by the overall nutrient depletion and starving of microorganisms over the 61 days of exposure (Chernozems $\mathrm{H}$ and $\mathrm{S}$ ), short-term dormancy effect of some pharmaceuticals, mainly fexofenadine, irbesartan and citalopram should be additionally studied in details.

\section{Practical application of the obtained results}

Based on our results, we propose a simplified conceptual scheme of the soil-pharmaceutical-time interaction (Fig. 5) that can be used as background for decision making in soil management related to contamination by emerging compounds. Our concept is based on integrative assessment of the soil, pharmaceutical properties and microbial activity. It includes a set of generally available indicators at different multi-disciplinary scales (soil and pharmaceuticals properties, parameters of microbial activity) and the following activities were performed (Fig. 5): (i) description of soil and pharmaceuticals properties; (ii) amendment of pharmaceuticals in soil; (iii) detection of effects (stimulatory, dormancy, inhibitory and stress); (iv) evaluation of microbial resilience by recovery of biomass and respiration and (v) mitigation of the effect when the recovery of biomass and respiration was not achieved in a certain type of soil. Taking into account that it is difficult to avoid soil contamination by pharmaceuticals during wastewater, sludge and manure application, we suggest that soil management should be focused on the facilitation of biodegradation of pharmaceuticals by stress reduction and inhibition prevention of soil microbial activity. Our concept is a first step towards determining microbial responses at different time intervals, the data provide important information on the mitigation of stress and inhibition of a microbial community facilitating the biodegradation of emerging compounds. For example, when we compare the responses of $13 \mathrm{~d}$ and $61 \mathrm{~d}$, we can determine if the microbial activity and biomass have recovered from the stress and inhibition by displaying stimulation or dormancy effects. These trends can be indicative for microbial resilience and determine needs in mitigation steps (e.g. increase of nutrients supply, decrease or stop pharmaceuticals inputs, etc.).

\section{Conclusion}

The presented microcosm experiment provides a unique opportunity to study the immediate ( $1 \mathrm{~d}$ ), short- (13 d) and long-term effects (61 d) of pharmaceutical application on microbial community changes in a representative set of European agricultural soils differing in physical chemical properties. Microbial responses are highly dependent on the soil type, pharmaceutical compound and time, highlighting the importance of considering these parameters in the evaluation of the effect. Even at low concentrations, pharmaceuticals have a negative effect on soil microorganisms. This effect (dormancy, inhibition or stress), however, is temporary. Our findings indicate that most of the effects are significant short-term while others remain during a longer exposure time. Here, soil microbial communities show resilience towards negative effects, since their biomass and activity recovered after an additional 7 weeks. Based on our method and the results obtained we provide a conceptual scheme to determine microbial responses under different exposure conditions, which may help to elucidate the effect of individual treatments on microbial activity, community size and structure in diverse soils. The proposed scheme considers the resilience of soil

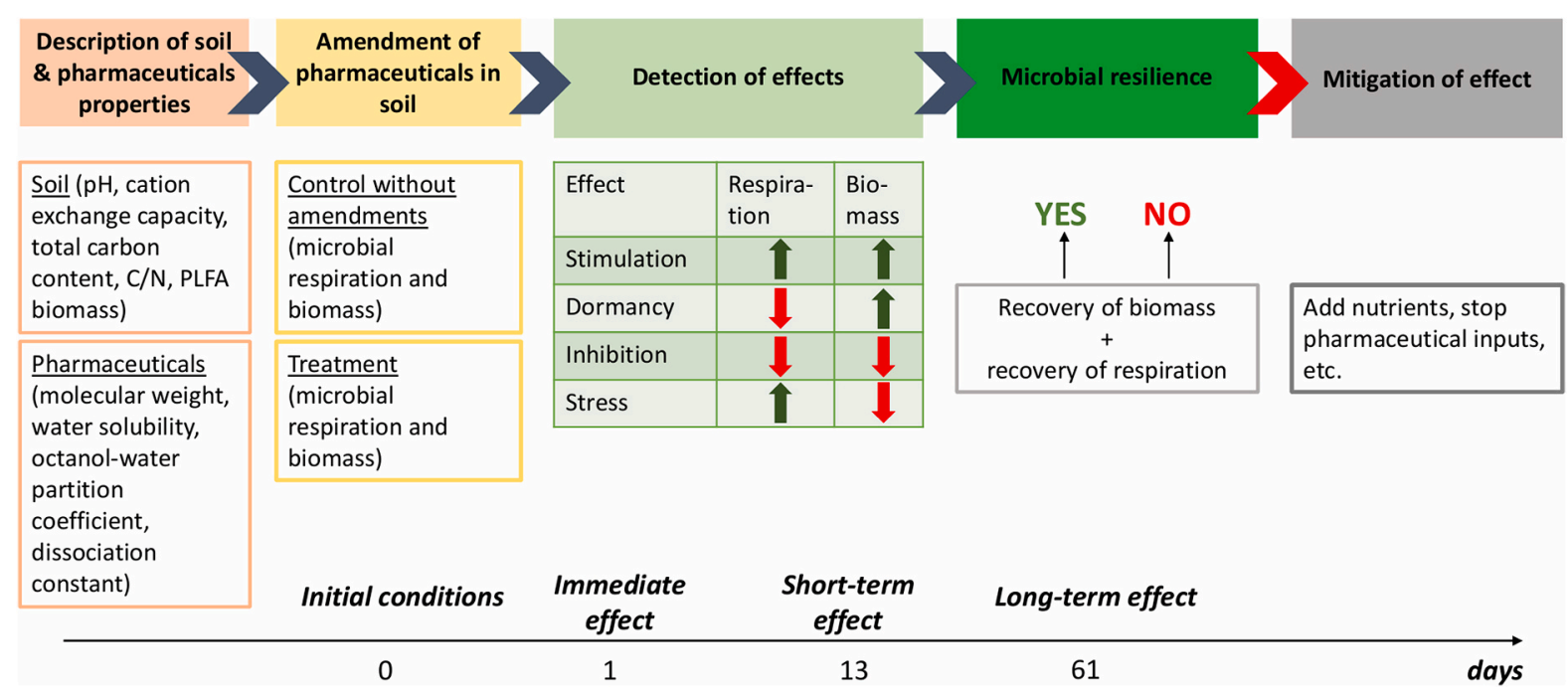

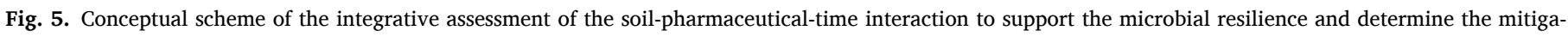
tion steps. 
microbial communities to micropollutants within long-term agricultural soil management.

\section{Data availability statement}

The data that support the findings of this study are openly available under CC-BY license in KNB repository at DOI: 10.5063/F1TD9VQ6, and all codes to process them are publicly available on GitHub repository at https://github.com/zuzabluza/microbial-responses_pharmaceuti cals_soil.

\section{Declaration of competing interest}

The authors declare that they have no known competing financial interests or personal relationships that could have appeared to influence the work reported in this paper.

\section{Acknowledgement}

This work was supported by The Czech Science Foundation (GACR) [grant number 17-08937S]. The authors thank to Aleš Klement, Miroslav Fér, Martin Kočárek and Antonín Nikodem for field sampling and experimental set up, Martina Petrlíková, Ludmila Kahounová and Anna Košinová for help with laboratory analyses, David Kahoun for accessing laboratory with GC-FID, Vilém Děd and Milan Ríha for help with data processing and visualization.

\section{Appendix A. Supplementary data}

Supplementary data to this article can be found online at https://doi. org/10.1016/j.soilbio.2020.107924.

\section{References}

Anderson, T.H., Domsch, K.H., 1985. Determination of ecophysiological maintenance carbon requirements of soil microorganisms in a dormant state. Biology and Fertility of Soils 1, 81-89. https://doi.org/10.1007/BF00255134.

Biel-Maeso, M., González-González, C., Lara-Martín, P.A., Corada-Fernández, C., 2019. Sorption and degradation of contaminants of emerging concern in soils under aerobic and anaerobic conditions. The Science of the Total Environment 666, 662-671. https://doi.org/10.1016/j.scitotenv.2019.02.279.

Bligh, E.G., Dyer, W.J., 1959. A rapid method of total lipid extraction and purification. Canadian Journal of Biochemistry and Physiology 37, 911-917. https://doi.org/ 10.1139/059-099.

Boix, C., Ibáñez, M., Sancho, J.V., Parsons, J.R., Voogt, P. de, Hernández, F., 2016. Biotransformation of pharmaceuticals in surface water and during waste water treatment: identification and occurrence of transformation products. Journal of Hazardous Materials 302, 175-187. https://doi.org/10.1016/j. jhazmat.2015.09.053.

Boxall, A.B.A., Blackwell, P., Cavallo, R., Kay, P., Tolls, J., 2002. The sorption and transport of a sulphonamide antibiotic in soil systems. Toxicology Letters 131, 19-28. https://doi.org/10.1016/S0378-4274(02)00063-2.

Brown, J.H., Gillooly, J.F., Allen, A.P., Savage, V.M., West, G.B., 2004. Toward a metabolic theory of ecology. Ecology 85, 1771-1789. https://doi.org/10.1890/039000.

Carter, L.J., Garman, C.D., Ryan, J., Dowle, A., Bergström, E., Thomas-Oates, J., Boxall, A.B.A., 2014. Fate and uptake of pharmaceuticals in soil-earthworm systems. Environmental Science and Technology. https://doi.org/10.1021/es500567w.

Chen, Y., Stemple, B., Kumar, M., Wei, N., 2016. Cell surface display fungal laccase as a renewable biocatalyst for degradation of persistent micropollutants bisphenol A and sulfamethoxazole. Environmental Science and Technology 50, 8799-8808. https:// doi.org/10.1021/acs.est.6b01641.

Cycoń, M., Borymski, S.S.S., Żołnierczyk, B., Piotrowska-Seget, Z., Cycon, M., Borymski, S.S.S., Zolnierczyk, B., Piotrowska-Seget, Z., 2016. Variable effects of nonsteroidal anti-inflammatory drugs (NSAIDs) on selected biochemical processes mediated by soil microorganisms. Frontiers in Microbiology 7, 1-19. https://doi. org/10.3389/fmicb.2016.01969.

Cycoń, M., Mrozik, A., Piotrowska-Seget, Z., 2019. Antibiotics in the soil environment-degradation and their impact on microbial activity and diversity. Frontiers in Microbiology. https://doi.org/10.3389/fmicb.2019.00338.

De Groot, R.S., Wilson, M.A., Boumans, R.M.J., 2002. A typology for the classification, description and valuation of ecosystem functions, goods and services. Ecological Economics. https://doi.org/10.1016/S0921-8009(02)00089-7.

Demoling, L.A., Bååth, E., Greve, G., Wouterse, M., Schmitt, H., 2009. Effects of sulfamethoxazole on soil microbial communities after adding substrate. Soil Biology and Biochemistry. https://doi.org/10.1016/j.soilbio.2009.02.001.
Ding, G.C., Radl, V., Schloter-Hai, B., Jechalke, S., Heuer, H., Smalla, K., Schloter, M., 2014. Dynamics of soil bacterial communities in response to repeated application of manure containing sulfadiazine. PloS One. https://doi.org/10.1371/journal. pone.0092958.

Dowling, N.J.E., Widdel, F., White, D.C., 1986. Phospholipid ester-linked fatty acid biomarkers of acetate-oxidizing sulphate-reducers and other sulphide-forming bacteria. Microbiology 135, 1815-1825. https://doi.org/10.1099/00221287-132-71815.

Elizalde-Velázquez, A., Gómez-Oliván, L.M., Islas-Flores, H., SanJuan-Reyes, N., GalarMartínez, M., García-Medina, S., Dublán-García, O., Hernández-Navarro, M.D., 2019. Ecotoxicological studies of pharmaceuticals in aquatic organisms. In: GómezOliván, L.M. (Ed.), Ecopharmacovigilance: Multidisciplinary Approaches to Environmental Safety of Medicines. Springer International Publishing, Cham, pp. 75-93. https://doi.org/10.1007/698_2017_148.

European Soil Bureau Network European Commission, 2005. Soil Atlas of Europe. Office for Official Publications of the European Communities, Luxembourg.

Fahrenfeld, N., Knowlton, K., Krometis, L.A., Hession, W.C., Xia, K., Lipscomb, E., Libuit, K., Green, B.L., Pruden, A., 2014. Effect of manure application on abundance of antibiotic resistance genes and their attenuation rates in soil: field-scale mass balance approach. Environmental Science and Technology 48, 2643-2650. https:// doi.org/10.1021/es404988k.

Fedorova, G., Randak, T., Golovko, O., Kodes, V., Grabicova, K., Grabic, R., 2014. A passive sampling method for detecting analgesics, psycholeptics, antidepressants and illicit drugs in aquatic environments in the Czech Republic. The Science of the Total Environment 487, 681-687. https://doi.org/10.1016/j.scitotenv.2013.12.091.

Fer, M., Kodešová, R., Golovko, O., Schmidtová, Z., Klement, A., Nikodem, A., Kočárek, M., Grabic, R., 2018. Sorption of atenolol, sulfamethoxazole and carbamazepine onto soil aggregates from the illuvial horizon of the haplic luvisol on loess. Soil and Water Research 13, 177-183. https://doi.org/10.17221/82/2018SWR.

Frostegård, Å., Tunlid, A., Baath, E., 1993. Phospholipid fatty-acid composition, biomass, and activity of microbial communities from two soil types experimentally exposed to different heavy-metals. Applied and Environmental Microbiology 59, 3605-3617.

Frostegård, Å., Tunlid, A., Bååth, E., 2011. Use and misuse of PLFA measurements in soils. Soil Biology and Biochemistry. https://doi.org/10.1016/j.soilbio.2010.11.021.

Gauthier, H., Yargeau, V., Cooper, D.G., 2010. Biodegradation of pharmaceuticals by Rhodococcus rhodochrous and Aspergillus Niger by co-metabolism. The Science of the Total Environment. https://doi.org/10.1016/j.scitotenv.2009.12.012.

Geisen, S., Mitchell, E.A.D., Adl, S., Bonkowski, M., Dunthorn, M., Ekelund, F., Fernández, L.D., Jousset, A., Krashevska, V., Singer, D., Spiegel, F.W., Walochnik, J., Lara, E., 2018. Soil protists: a fertile frontier in soil biology research. FEMS Microbiology Reviews 42, 293-323. https://doi.org/10.1093/femsre/fuy006.

Gielen, G.J.H.P., Clinton, P.W., Van den Heuvel, M.R., Kimberley, M.O., Greenfield, L.G., 2011. Influence of sewage and pharmaceuticals on soil microbial function. Environmental Toxicology \& Chemistry 30, 1086-1095. https://doi.org/10.1002/ etc. 487 .

Golovko, O., Koba, O., Kodesova, R., Fedorova, G., Kumar, V., Grabic, R., 2016. Development of fast and robust multiresidual LC-MS/MS method for determination of pharmaceuticals in soils. Environmental Science and Pollution Research 23, 14068-14077. https://doi.org/10.1007/s11356-016-6487-6.

Golovko, O., Kumar, V., Fedorova, G., Randak, T., Grabic, R., 2014a. Seasonal changes in antibiotics, antidepressants/psychiatric drugs, antihistamines and lipid regulators in a wastewater treatment plant. Chemosphere $111,418-426$. https://doi.org/ 10.1016/j.chemosphere.2014.03.132.

Golovko, O., Kumar, V., Fedorova, G., Randak, T., Grabic, R., 2014b. Removal and seasonal variability of selected analgesics/anti-inflammatory, anti-hypertensive/ cardiovascular pharmaceuticals and UV filters in wastewater treatment plant. Environmental Science and Pollution Research 21, 7578-7585. https://doi.org/ 10.1007/s11356-014-2654-9.

Goodman, I.S., Gilman, A., 2011. The pharmacological basis of therapeutics. In: Journal of Medicinal Chemistry, twelfth ed. McGraw-Hill, New York. https://doi.org/ 10.1021/jm00324a062.

Gottschall, N., Topp, E., Metcalfe, C., Edwards, M., Payne, M., Kleywegt, S., Russell, P., Lapen, D.R., 2012. Pharmaceutical and personal care products in groundwater, subsurface drainage, soil, and wheat grain, following a high single application of municipal biosolids to a field. Chemosphere 87, 194-203. https://doi.org/10.1016/ j.chemosphere.2011.12.018.

Grossberger, A., Hadar, Y., Borch, T., Chefetz, B., 2014. Biodegradability of pharmaceutical compounds in agricultural soils irrigated with treated wastewater. Environmental Pollution. https://doi.org/10.1016/j.envpol.2013.10.038.

Gutiérrez, I.R., Watanabe, N., Harter, T., Glaser, B., Radke, M., 2010. Effect of sulfonamide antibiotics on microbial diversity and activity in a Californian Mollic Haploxeralf. Journal of Soils and Sediments 10, 537-544. https://doi.org/10.1007/ s11368-009-0168-8.

Heuer, H., Focks, A., Lamshöft, M., Smalla, K., Matthies, M., Spiteller, M., 2008. Fate of sulfadiazine administered to pigs and its quantitative effect on the dynamics of bacterial resistance genes in manure and manured soil. Soil Biology and Biochemistry 40, 1892-1900. https://doi.org/10.1016/j.soilbio.2008.03.014.

Höltge, S., Kreuzig, R., 2007. Laboratory testing of sulfamethoxazole and its metabolite acetyl-sulfamethoxazole in soil. Clean - Soil, Air, Water 35, 104-110. https://doi. org/10.1002/clen.200600019.

Hothorn, T., Bretz, F., Westfall, P., 2008. Simultaneous inference in general parametric models. Biometrical Journal 50, 346-363. https://doi.org/10.1002/ bimj. 200810425.

Ivanová, L., Mackulak, T., Grabic, R., Golovko, O., Koba, O., Staňová, A.V., Szabová, P., Grenčíková, A., Bodík, I., 2018. Pharmaceuticals and illicit drugs - a new threat to 
the application of sewage sludge in agriculture. The Science of the Total Environment. https://doi.org/10.1016/j.scitotenv.2018.04.001.

Jechalke, S., Focks, A., Rosendahl, I., Groeneweg, J., Siemens, J., Heuer, H., Smalla, K., 2014. Structural and functional response of the soil bacterial community to application of manure from difloxacin-treated pigs. FEMS Microbiology Ecology. https://doi.org/10.1111/1574-6941.12191.

Johansen, A., Olsson, S., 2005. Using phospholipid fatty acid technique to study shortterm effects of the biological control agent Pseudomonas fluorescens DR54 on the microbial microbiota in barley rhizosphere. Microbial Ecology 49, 272-281. https:// doi.org/10.1007/s00248-004-0135-2.

Jurado, A., Walther, M., Díaz-Cruz, M.S., 2019. Occurrence, fate and environmental risk assessment of the organic microcontaminants included in the Watch Lists set by EU Decisions 2015/495 and 2018/840 in the groundwater of Spain. The Science of the Total Environment 663, 285-296. https://doi.org/10.1016/j.scitotenv.2019.01.270.

Kinney, C.A., Furlong, E.T., Werner, S.L., Cahill, J.D., 2006. Presence and distribution of wastewater-derived pharmaceuticals in soil irrigated with reclaimed water. Environmental Toxicology \& Chemistry. https://doi.org/10.1897/05-187R.1.

Klement, A., Kodešová, R., Bauerová, M., Golovko, O., Kočárek, M., Fér, M., Koba, O., Nikodem, A., Grabic, R., 2018. Sorption of citalopram, irbesartan and fexofenadine in soils: estimation of sorption coefficients from soil properties. Chemosphere 195, 615-623. https://doi.org/10.1016/j.chemosphere.2017.12.098.

Klement, A., Kodešová, R., Golovko, O., Fér, M., Nikodem, A., Ko, M., Grabic, R., 2020. Uptake, translocation and transformation of three pharmaceuticals in green pea plants. Journal of Hydrology and Hydromechanics 68, 1-11. https://doi.org/ 10.2478/johh-2020-0001.

Koba, O., Golovko, O., Kodešová, R., Fér, M., Grabic, R., 2017. Antibiotics degradation in soil: a case of clindamycin, trimethoprim, sulfamethoxazole and their transformation products. Environmental Pollution 220, 1251-1263. https://doi.org/10.1016/j. envpol.2016.11.007.

Koba, O., Golovko, O., Kodešová, R., Klement, A., Grabic, R., 2016. Transformation of atenolol, metoprolol, and carbamazepine in soils: the identification, quantification, and stability of the transformation products and further implications for the environment. Environmental Pollution 218, 574-585. https://doi.org/10.1016/j. envpol.2016.07.041.

Kodešová, Radka, Chroňáková, Alica, Grabicová, Kateřina, Kočárek, Martin, Schmidtová, Zuzana, Frková, Zuzana, Vojs Staňová, Andrea, Nikodem, Antonín, Klement, Aleš, Fér, Miroslav, Grabic, Roman, 2020. How microbial community composition, sorption and simultaneous application of six pharmaceuticals affect their dissipation in soils. Science of the Total Environment, 141134. https://doi.org/ 10.1016/j.scitotenv.2020.141134. In press.

Kodešová, R., Grabic, R., Kočárek, M., Klement, A., Golovko, O., Fér, M., Nikodem, A. Jakšík, O., 2015. Pharmaceuticals' sorptions relative to properties of thirteen different soils. The Science of the Total Environment 511, 435-443. https://doi.org/ 10.1016/j.scitotenv.2014.12.088.

Kodešová, R., Klement, A., Golovko, O., Fér, M., Kočárek, M., Nikodem, A., Grabic, R., 2019a. Soil influences on uptake and transfer of pharmaceuticals from sewage sludge amended soils to spinach. Journal of Environmental Management 250, 109407. https://doi.org/10.1016/j.jenvman.2019.109407.

Kodešová, R., Klement, A., Golovko, O., Fér, M., Nikodem, A., Kočárek, M., Grabic, R., 2019b. Root uptake of atenolol, sulfamethoxazole and carbamazepine, and their transformation in three soils and four plants. Environmental Science and Pollution Research 26, 9876-9891. https://doi.org/10.1007/s11356-019-04333-9.

Kodešová, R., Kočárek, M., Klement, A., Golovko, O., Koba, O., Fér, M., Nikodem, A., Vondráčková, L., Jakšík, O., Grabic, R., 2016. An analysis of the dissipation of pharmaceuticals under thirteen different soil conditions. The Science of the Total Environment 544, 369-381. https://doi.org/10.1016/j.scitotenv.2015.11.085.

Kota, S., Borden, R.C., Barlaz, M.A., 1999. Influence of protozoan grazing on contaminant biodegradation. FEMS Microbiology Ecology 29, 179-189. https://doi. org/10.1016/S0168-6496(99)00010-0.

Kotas, P., Santruckova, H., Elster, J., Kastovska, E., 2018. Soil microbial biomass, activity and community composition along altitudinal gradients in the High Arctic (Billefjorden, Svalbard). Biogeosciences. https://doi.org/10.5194/bg-15-1879-2018.

Kümmerer, K., 2009. The presence of pharmaceuticals in the environment due to human use - present knowledge and future challenges. Journal of Environmental Management. https://doi.org/10.1016/j.jenvman.2009.01.023.

Kyselková, M., Jirout, J., Chronáková, A., Vrchotová, N., Bradley, R., Schmitt, H., Elhottová, D., 2013. Cow excrements enhance the occurrence of tetracycline resistance genes in soil regardless of their oxytetracycline content. Chemosphere 93 2413-2418. https://doi.org/10.1016/j.chemosphere.2013.08.058.

Larcher, S., Yargeau, V., 2011. Biodegradation of sulfamethoxazole by individual and mixed bacteria. Applied Microbiology and Biotechnology. https://doi.org/10.1007/ s00253-011-3257-8.

Lê, S., Josse, J., Husson, F., 2008. FactoMineR: an R package for multivariate analysis. Journal of Statistical Software. https://doi.org/10.18637/jss.v025.i01.

Li, J., Dodgen, L., Ye, Q., Gan, J., 2013. Degradation kinetics and metabolites of carbamazepine in soil. Environmental Science and Technology 47, 3678-3684. https://doi.org/10.1021/es304944c.

Lin, K., Gan, J., 2011. Sorption and degradation of wastewater-associated non-steroidal anti-inflammatory drugs and antibiotics in soils. Chemosphere 83, 240-246. https:// doi.org/10.1016/j.chemosphere.2010.12.083.

Liu, A., Cao, H., Yang, Y., Ma, X., Liu, X., 2016. Combinational effects of sulfomethoxazole and copper on soil microbial community and function. Environmental Science and Pollution Research 23, 4235-4241. https://doi.org/ 10.1007/s11356-015-4892-x.

Liu, F., Wu, J., Ying, G.G., Luo, Z., Feng, H., 2012. Changes in functional diversity of soil microbial community with addition of antibiotics sulfamethoxazole and chlortetracycline. Applied Microbiology and Biotechnology 95, 1615-1623. https:// doi.org/10.1007/s00253-011-3831-0.

Liu, F., Ying, G.G., Tao, R., Zhao, J.L., Yang, J.F., Zhao, L.F., 2009. Effects of six selected antibiotics on plant growth and soil microbial and enzymatic activities. Environmental Pollution 157, 1636-1642. https://doi.org/10.1016/j. envpol.2008.12.021.

Liu, F., Ying, G.G., Yang, J.F., Zhou, L.J., Tao, R., Wang, L., Zhang, L.J., Peng, P.A., 2010. Dissipation of sulfamethoxazole, trimethoprim and tylosin in a soil under aerobic and anoxic conditions. Environmental Chemistry 7, 370-376. https://doi.org/ 10.1071/EN09160.

Löffler, D., Römbke, J., Meller, M., Ternes, T.A., 2005. Environmental fate of pharmaceuticals in water/sediment systems. Environmental Science and Technology 39, 5209-5218. https://doi.org/10.1021/es0484146.

Majewsky, M., Wagner, D., Delay, M., Bräse, S., Yargeau, V., Horn, H., 2014. Antibacterial activity of sulfamethoxazole transformation products (TPs): general relevance for sulfonamide TPs modified at the para position. Chemical Research in Toxicology 27, 1821-1828. https://doi.org/10.1021/tx500267x.

Martínez-Hernández, V., Meffe, R., Herrera López, S., de Bustamante, I., 2016. The role of sorption and biodegradation in the removal of acetaminophen, carbamazepine, caffeine, naproxen and sulfamethoxazole during soil contact: a kinetics study. The Science of the Total Environment 5559, 232-241. https://doi.org/10.1016/j. scitotenv.2016.03.131.

Matheson, F.E., 2008. Microcosms. In: Jørgensen, S.E., Fath, B.D.B.T.-E. (Eds.), Encyclopedia of Ecology. Academic Press, Oxford, pp. 2393-2397. https://doi.org/ 10.1016/B978-008045405-4.00064-1.

Molaei, A., Lakzian, A., Haghnia, G., Astaraei, A., Rasouli-Sadaghiani, M.H., Ceccherini, M.T., Datta, R., 2017. Assessment of some cultural experimental methods to study the effects of antibiotics on microbial activities in a soil: an incubation study. PloS One. https://doi.org/10.1371/journal.pone.0180663.

Monteiro, S.C., Boxall, A.B.A., 2009. Factors affecting the degradation of pharmaceuticals in agricultural soils. Environmental Toxicology \& Chemistry 28, 2546-2554. https://doi.org/10.1897/08-657.1.

Oksanen, J., Guillaume Blanchet, F., Kindt, R., Legendre, P., Minchin, P.R., O'Hara, R.B., Simpson, G.L., Solymos, P., Stevens, M. Henry H., Wagner, H., 2019. Package 'vegan.' R Package, Version 3.4.0.

Ooi, G.T.H., Escola Casas, M., Andersen, H.R., Bester, K., 2017. Transformation products of clindamycin in moving bed biofilm reactor (MBBR). Water Research 113, 139-148. https://doi.org/10.1016/j.watres.2017.01.058.

Pino-Otín, M.R., Muñiz, S., Val, J., Navarro, E., 2017. Effects of 18 pharmaceuticals on the physiological diversity of edaphic microorganisms. The Science of the Total Environment. https://doi.org/10.1016/j.scitotenv.2017.04.002.

Popa Ungureanu, C., Favier, L., Bahrim, G., Amrane, A., 2014. Response surface optimization of experimental conditions for carbamazepine biodegradation by Streptomyces. MIUG 4, 89. https://doi.org/10.1016/j.nbt.2014.12.005. New Biotechnology.

Porubcan, L.S., Serna, C.J., White, J.L., Hem, S.L., 1978. Mechanism of adsorption of clindamycin and tetracycline by montmorillonite. Journal of Pharmaceutical Sciences 67, 1081-1087. https://doi.org/10.1002/jps.2600670815.

Radke, M., Lauwigi, C., Heinkele, G., Múrdter, T.E., Letzel, M., 2009. Fate of the antibiotic sulfamethoxazole and its two major human metabolites in a water sediment test. Environmental Science and Technology 43, 3135-3141. https://doi org/10.1021/es900300u.

Rodarte-Morales, A.I., Feijoo, G., Moreira, M.T., Lema, J.M., 2011. Degradation of selected pharmaceutical and personal care products (PPCPs) by white-rot fungi. World Journal of Microbiology and Biotechnology 27, 1839-1846. https://doi.org/ 10.1007/s11274-010-0642-x.

Rubasinghege, G., Gurung, R., Rijal, H., Maldonado-Torres, S., Chan, A., Acharya, S., Rogelj, S., Piyasena, M., 2018. Abiotic degradation and environmental toxicity of ibuprofen: roles of mineral particles and solar radiation. Water Research. https:// doi.org/10.1016/j.watres.2017.12.016.

Rui, Y., Murphy, D.V., Wang, X., Hoyle, F.C., 2016. Microbial respiration, but not biomass, responded linearly to increasing light fraction organic matter input: consequences for carbon sequestration. Scientific Reports 6, 1-9. https://doi.org/ 10.1038/srep35496.

Schmidtová, Z., Kodešová, R., Grabicová, K., Kočárek, M., Fér, M., Švecová, H., Klement, A., Nikodem, A., Grabic, R., 2020. Competitive and synergic sorption of carbamazepine, citalopram, clindamycin, fexofenadine, irbesartan and sulfamethoxazole in seven soils. Journal of Contaminant Hydrology. https://doi.org/ 10.1016/j.jconhyd.2020.103680 (in press).

Shah, R.P., Sahu, A., Singh, S., 2010. Identification and characterization of degradation products of irbesartan using LC-MS/TOF, MSn, on-line H/D exchange and LC-NMR. Journal of Pharmaceutical and Biomedical Analysis 51, 1037-1046. https://doi.org/ 10.1016/j.jpba.2009.11.008.

Sinclair, J.L., Kampbell, D.H., Cook, M.L., Wilson, J.T., 1993. Protozoa in subsurface sediments from sites contaminated with aviation gasoline or jet fuel. Applied and Environmental Microbiology 59, 467-472.

Srinivasan, P., Sarmah, A.K., 2014. Dissipation of sulfamethoxazole in pasture soils as affected by soil and environmental factors. The Science of the Total Environment 479-480, 284-291. https://doi.org/10.1016/j.scitotenv.2014.02.014.

Stokes, H.W., Gillings, M.R., 2011. Gene flow, mobile genetic elements and the recruitment of antibiotic resistance genes into Gram-negative pathogens. FEMS Microbiology Reviews 35, 790-819. https://doi.org/10.1111/j.15746976.2011.00273.x.

Thelusmond, J.R., Kawka, E., Strathmann, T.J., Cupples, A.M., 2018. Diclofenac, carbamazepine and triclocarban biodegradation in agricultural soils and the microorganisms and metabolic pathways affected. The Science of the Total 
Environment 1393-1410. https://doi.org/10.1016/j.scitotenv.2018.05.403, 640-641.

Thelusmond, J.R., Strathmann, T.J., Cupples, A.M., 2019. Carbamazepine, triclocarban and triclosan biodegradation and the phylotypes and functional genes associated with xenobiotic degradation in four agricultural soils. The Science of the Total Environment 657, 1138-1149. https://doi.org/10.1016/j.scitotenv.2018.12.145.

Thelusmond, J.R., Strathmann, T.J., Cupples, A.M., 2016. The identification of carbamazepine biodegrading phylotypes and phylotypes sensitive to carbamazepine exposure in two soil microbial communities. The Science of the Total Environment 571, 1241-1252. https://doi.org/10.1016/j.scitotenv.2016.07.154.

Tiehm, A., Schmidt, N., Stieber, M., Sacher, F., Wolf, L., Hoetzl, H., 2011. Biodegradation of phmaceutical compounds and their occurrence in the Jordan valley. Water Resources Management 25, 1195-1203. https://doi.org/10.1007/s11269-010-96789.

Topp, E., Chapman, R., Devers-Lamrani, M., Hartmann, A., Marti, R., Martin-Laurent, F., Sabourin, L., Scott, A., Sumarah, M., 2013. Accelerated biodegradation of veterinary antibiotics in agricultural soil following long-term exposure, and isolation of a sulfamethazinedegrading microbacterium sp. Journal of Environmental Quality. https://doi.org/10.2134/jeq2012.0162.

Topp, E., Hendel, J.G., Lapen, D.R., Chapman, R., 2008. Fate of the nonsteroidal antiinflammatory drug naproxen in agricultural soil receiving liquid municipal biosolids. Environmental Toxicology \& Chemistry. https://doi.org/10.1897/07-644.1.

Van Bodegom, P., 2007. Microbial maintenance: a critical review on its quantification. Microbial Ecology 53, 513-523. https://doi.org/10.1007/s00248-006-9049-5.

Vasiliadou, I.A., Molina, R., Martínez, F., Melero, J.A., 2013. Biological removal of pharmaceutical and personal care products by a mixed microbial culture: sorption, desorption and biodegradation. Biochemical Engineering Journal. https://doi.org/ 10.1016/j.bej.2013.10.010.

Vystavna, Y., Frkova, Z., Marchand, L., Vergeles, Y., Stolberg, F., 2017. Removal efficiency of pharmaceuticals in a full scale constructed wetland in East Ukraine. Ecological Engineering. https://doi.org/10.1016/j.ecoleng.2017.08.009.

Vystavna, Y., Schmidt, S.I., Diadin, D., Rossi, P.M., Vergeles, Y., Erostate, M., Yermakovych, I., Yakovlev, V., Knöller, K., Vadillo, I., 2019. Multi-tracing of recharge seasonality and contamination in groundwater: a tool for urban water resource management. Water Research 161, 413-422. https://doi.org/10.1016/J. WATRES.2019.06.028.

Weetman, G.F., Fournier, R., 1982. Graphical diagnosis of lodgepole pine response to fertilization. Soil Science Society of America Journal 46, 1280-1289.

Willers, C., Jansen van Rensburg, P.J., Claassens, S., 2015. Microbial signature lipid biomarker analysis - an approach that is still preferred, even amid various method modifications. Journal of Applied Microbiology 118, 1251-1263. https://doi.org/ 10.1111/jam.12798.

Williams, C.F., Williams, C.F., Adamsen, F.J., 2006. Sorption-Desorption of carbamazepine from irrigated soils. Journal of Environmental Quality. https://doi. org/10.2134/jeq2005.0345.

Wu, C., Spongberg, A.L., Witter, J.D., Fang, M., Czajkowski, K.P., Ames, A., 2010. Dissipation and leaching potential of selected pharmaceutically active compounds in soils amended with biosolids. Archives of Environmental Contamination and Toxicology 59, 343-351. https://doi.org/10.1007/s00244-010-9500-y.

Xu, J., Wu, L., Chang, A.C., 2009. Degradation and adsorption of selected pharmaceuticals and personal care products (PPCPs) in agricultural soils. Chemosphere. https://doi.org/10.1016/j.chemosphere.2009.09.063.

Zhang, Y., Hu, S., Zhang, H., Shen, G., Yuan, Z., Zhang, W., 2017. Degradation kinetics and mechanism of sulfadiazine and sulfamethoxazole in an agricultural soil system with manure application. The Science of the Total Environment. https://doi.org/ 10.1016/j.scitotenv.2017.07.083.

Zielezny, Y., Groeneweg, J., Vereecken, H., Tappe, W., 2006. Impact of sulfadiazine and chlorotetracycline on soil bacterial community structure and respiratory activity. Soil Biology and Biochemistry 38, 2372-2380. https://doi.org/10.1016/j. soilbio.2006.01.031.

Zumstein, M.T., Helbling, D.E., 2019. Biotransformation of antibiotics: exploring the activity of extracellular and intracellular enzymes derived from wastewater microbial communities. Water Research 155, 115-123. https://doi.org/10.1016/j. watres.2019.02.024. 